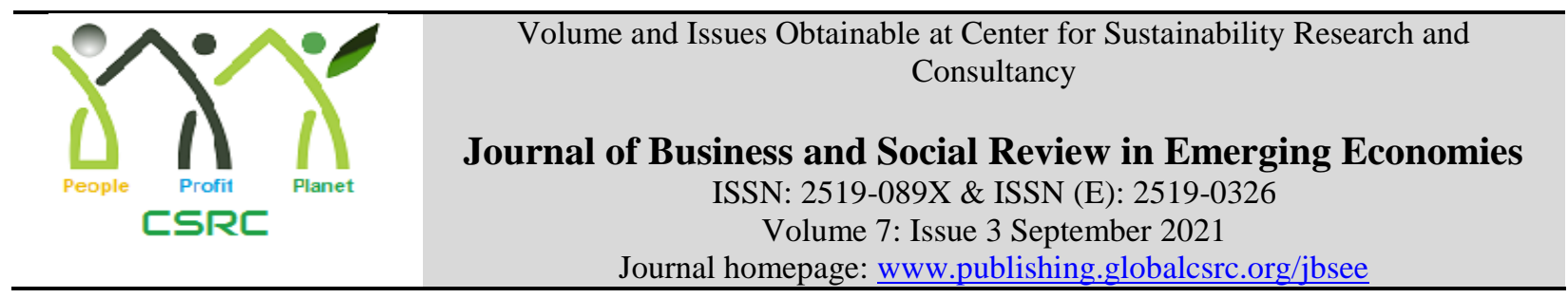

\title{
R\&D Expenditure as an Accelerator of Economic Growth with Special Reference to Developing Countries
}

*Tariq Mahmood Ali, Health Service Academy, Islamabad, Visiting Academic, Manchester Institute of Innovation Research(MIoIR) Alliance Manchester Business School (AMBS)1 / The University of Manchester, UK

Adiqa Kausar Kiani, Federal Urdu University of Science and Technology, Islamabad, Pakistan Tariq Bashir, Pakistan Council for Science and Technology, Islamabad, Pakistan

Talah Numan Khan, Forman Christian College (A Chartered University), Lahore, Pakistan

*Corresponding author's email: tariqali@ hsa.edu.pk

\begin{tabular}{l} 
ARTICLE DETAILS \\
\hline History \\
Revised format: Aug 2021 \\
Available Online: Sep 2021 \\
Keywords \\
R\&D $\quad$ Expenditure, \\
Economic Growth, Panel \\
Data, ARD model
\end{tabular}

JEL Classification

O, O3, O32, O4, 047

\begin{abstract}
Purpose: In this network age, among the other factors which increase economic growth, the R\&D activities, a pivotal and effective factor, carried out by a country. The present study attempts to investigate the empirical R\&D expenditure-economic growth nexus in developing and developed economies, and also provides useful insight about how R\&D investment works to enhance the economic growth of a country.
\end{abstract}

Design/Methodology/Approach: In this regard, 21 years data of top 100 economies of the world from 1995 to 2015 has been utilized. The Panel ARD Model approach has been preferred to explore the impact of R\&D investment on economic growth (GDP). For construction of the estimation model, five different variables are used. In order to accomplish the results, along with analysing the data of 100 countries a whole, analysis has also been made by dividing countries into different categories and groups. Overall, the Panel ARDL test has been performed on nine different groups of countries.

Findings: The results reveal that, ceteris paribus, there is a strong positive association between R\&D expenditure and economic growth (GDP) in the long-run; $1 \%$ increase in GERD leads to $0.07 \%$ increase in GDP. However, the impact in the developing countries $(0.043 \%)$ is lower compared to the developed OECD countries $(0.27 \%)$. No impact of the R\&D expenditure on economic growth is observed in the short-run.

Implications/Originality/Value: The study presents some thoughtprovoking ideas, policy recommendations and implications for the policy makers, planners and researchers, especially in the context of developing economies.

Recommended citation: Ali, T.M., Kiani, A. K, Bashir, T. and Khan, T.N. (2021). R\&D Expenditure as an Accelerator of Economic Growth with Special Reference to Developing 


\section{Countries. Journal of Business and Social Review in Emerging Economies. 7( 3), 561-589.}

*Author's Note: The author had been awarded IRSIP Scholarship by Higher Education Commission (HEC), Pakistan, to complete his PhD research work at MIoIR, AMBS, The University of Manchester, UK in 2017 as a visiting academic. This paper is from his $\mathrm{PhD}$ doctoral dissertation. He is grateful to his supervisors and HEC for IRSIP scholarship.

\section{Introduction}

Economic growth always is a tricky question for economists and researchers as it is a complex issue and it is difficult to understand the phenomena of economic growth. However, the factors affecting economic growth are very imperative. Solow (1956) presented the production function with capital, labour, and technological progress laying down the foundation of classical growth theory. He believes that technological progress is exogenous and that the economy converges to a stable state of zero growth. Later on, the new growth theory drew attention to the endogenous role of technological progress in the economic growth of world economies. According to the new growth theory, augmented growth model is utilized to calculate the long-term growth, so called endogenous growth model where the growth of the country is measured by a number of factors like increasing return to scale, openness of trade, international research and development expenditure and human capital formation (Romer, 1986; Lucas, 1988). The key factors that support the economic growth can be stated as; i) physical capital accumulation (land, equipment, human resources, new investments), ii) growth of population (labour force), and iii) technological progress (Todaro, 1997). While the new growth theory emphasizes the significance of technological change as a cause of economic growth. Endogenous growth model based on research and development (called $\mathrm{R} \& \mathrm{D}$ model), seem the idea to follow Schumpeter's importance of innovation; the role of innovation (organized knowledge creation) in generating economic growth (Schumpeter, 1942). These concepts and theories were based on creative destruction (Ayres \& Warr, 2009). New technological creations are produced through research and development by utilizing the stock of knowledge and human capital. Finally, they are used in the production process of goods and lead to the permanent increase in the economic growth (Romer, 1986). Three famous studies, on the endogenous growth model based on R\&D, were carried out by Romer (1990), Grossman and Helpman (1991), and Aghion and Howitt (1992) which claimed that basic driver for economic growth is the R\&D activities.

These models can be considered as a complement to traditional models of growth (Bilbao-Osorio and Rodriguez, 2004). The empirical studies that test endogenous growth model, in general, base on the influence of variables on total factor productivity (TFP) growth. For example, to test the legitimacy of R\&D growth model, time series data about the growth rate of the number of scientists and engineers in France, Germany, Japan and USA was used by Jhones (1995b) and explored no relation among these variables. While Aghion and Howitt (1998) provided results which were contradictory to Jhones. They found a positive association in economy and stock of knowledge. Further, they contended that GERD as a percentage of GDP should be used in place of the number of scientists and engineers. Earlier, Romer (1994) has also reported similar results that $R \& D$ has a major contribution in innovation, increasing the productivity, and enhancing the economic growth.

In the first decade of the 21 st century, many studies were conducted to verify the impact of R \& $\mathrm{D}$, spending on economic growth, and these studies inferred a positive relation in their respective ways (Frantzen, 2000; Griffith, Redding Reenen,2004; Kaur and Singh,2016). Ulku (2004) endorsed that the positive relation exists between countries own R\&D \& innovation and productivity growth \& economic growth. Another recent time study, Crespi and Zungia (2011), found weak linkage between R\&D and economic growth in six Latin American countries. Inekwe (2015) revealed a positive impact of $R \& D$ on economic growth in the developing countries, while indicating higher impact of $\mathrm{R} \& \mathrm{D}$ investment on economic growth in the upper middle 
countries and insignificant impact for lower income countries. In most of these studies, technological progress has maintained a dynamic as an engine of economic growth. No doubt, the technological progress, through $\mathrm{R} \& \mathrm{D}$, in modern knowledge based economies is considered as the main contributor to growth of individual business/ factory/ firm, and resultantly, enhancement of overall economic growth of the country.

\section{Short Comings and Research Gaps}

During the literature review, we found shortcomings in the studies that have been conducted previously. While several studies have been conducted to investigate the impact of $R \& D$ expenditure on economic growth, the results and conclusions from these studies are different. The Researchers studied developed and developing economies by integrating different datasets through the panel estimation, and co-integration. These methods mostly contain econometric techniques for assessment of exogenous growth models with slight modifications, while some have employed growth accounting methods that include calculation of the rate of return for R\&D stock, surveys and case study analysis. Mostly the researchers have used a small set of data for their studies. As per our literature review, maximum numbers of countries included in a study are 66 which included 23 developing countries. Most of the studies used one or two traditional independent variables, like labour force and human capital along with R\&D expenditure. We could not find literature in which the controls and experimental variables have been used (to overcome the issues of endogeneity, correlation, normality etc.) for analysis which are essential for real econometric estimation. The studies focused more on empirical evidence of impact of $\mathrm{R} \& \mathrm{D}$ on economic growth rather than on the insights into the process that how R\&D investment impact economic growth.

However, the relationship between $\mathrm{R}$ \& $\mathrm{D}$ spending and economic growth is not firmly established in developing countries. Some of the shortcomings observed in the literature may be due to the differences in survey and sampling methodologies. From theoretical framework perspective, it has been focused that the role of diffusion and adoption of technologies is important than R\&D and innovation as it is a pre-requisite for learning and catching up (Bell \& Pavitt, 1993; Katz, 1986). Most previous studies on developing countries had been replicated on the agendas of developed countries; a focus on R \& D spending as the only source of economic growth, creativity and innovation. It is therefore not surprising that the findings on the link between economic growth and investment in research and development are inconsistent. Therefore, there is a dire need to study the relationship between R \& D investment and economic growth, providing a large sample of data, that is, long-term analysis of more countries. It is also important to explore ways to gain insight into processes or R \& D investment efforts to promote economic growth.

\section{Research Questions}

As stated earlier, there is dire need to make a comprehensive empirical study with a large sample of data to fill the existing research gaps. The real question is whether the nexus between $R \& D$ and economic growth be proved with a large sample of 100 countries? Whether the impact of $\mathrm{R} \& \mathrm{D}$ investment is similar in developing countries as it is in the developed countries? How does the R\&D investment enhance the economic growth? What is the process insight?

\section{Objectives of the Study}

To address the research questions, following are the major objectives of the study:

1. To find out the impact of $R \& D$ expenditure on economic growth empirically for top 100 economies of the world by using appropriate econometric techniques.

2. To find out the influence of $R \& D$ investment in developing countries, especially in East and South Asian countries. 
3. To explore the process insight of $R \& D$ investment in inventions, innovations, new creations and technologies.

\section{Significance and Novelty of the Study}

The purpose of the study was to fill gaps and gaps in the literature study by estimating a model of economic harmonized and compatibility. The aim is to verify whether the low productivity in some economies is due to low investment on an aggregate stock of knowledge and R\&D. The study applies the different econometric techniques to measure the income growth across 100 countries caused by $R \& D$ investments. The study has contributed to literature by investigating the differences in growth in developing and developed countries respectively through R\&D investment. It also investigates the contributions of $R \& D$ towards growth in both set of economies when studied as a single unit. While, our research has some common features with previous studies, its contributions to the prevailing literature are threefold:

i) The previous studies used small set of data for countries (maximum 66 countries, 23 for developing countries) while the current study investigates the effect of R\&D investment on economic growth (GDP) empirically for top 100 economies of the world comprised of both developed and developing countries. For more detailed and meaningful analysis, comparisons have been made between the groups of countries divided into three categories: i) OECD and Non OECD countries, ii) Developed and developing countries, and iii) East Asian and South Asian countries. Different econometric techniques have been applied to enhance the ethnicity of results.

ii) ARDL Panel approach is employed for the first-time in such type of analysis. The study contributes to the pertinent topic by controlling endogeneity, correlation and normality problems by instrument rationality among variables. R\&D personnel and employed labour force minus R\&D personnel have been included in the model specification to enhance the model reliability and increase the accuracy of results as per requirements of the theoretical endogenous growth theories. Furthermore, the study also makes contributions to existing R\&D literature through the provision of dynamic short and long run behaviour of variables in the specific models.

iii) The study explores the process insight of $R \& D$ investment and explains the channels through which R\&D investment would be able to accelerate economic growth in the context of developing countries. The study proposes the 'R\&D diamond model' for developing countries to enhance their absorptive capacity. The study provides policy recommendations which would be useful for students of economics, researchers, economists and S\&T policy makers.

The paper organized can stated as; section one and two, are about introduction and literature review respectively. Process insight of $R \& D$ investment and its trends are discussed in section three. Section four explains the empirical estimations while section five explains the results and discussions. In final section (i.e. section six), the study presents conclusions, policy recommendations and implications.

\section{Literature Review}

Research and development expenditures in the field of science and technology were considered to be one of the key criteria for measuring their economic development. Since, the R\&D expenditure affect economic growth through different channels like capital, invention, creation, human development etc. All of these factors contribute to the path for economic development (Bor, Chuang, Lai, \&Yang., 2010). The notion that the technology changes have a vital role in economic growth first entered in economic science when neoclassical economists began to support this concept. The neoclassical growth theory stands on the Robert Solow's model (Solow, 1956) which concludes that about 50\% growth of industrialized countries could not be accredited to the increasing use of physical capital and labour, but to the third factor; the so- 
called residual value (Solow, 1957). He argued that residual value is responsible for all imperceptible growth factors like research and development, capacity building of employees, human skills development and production techniques. Swan (1956) also worked almost on the same pattern. In this way, neo classical economists set the direction for study of this very imperative driver of economic growth. However, the neoclassical economists completely ignored the idea of the source of technical change which is the main shortcoming of this theory. Neoclassical economists did not fully explain the difference between residual values of different countries which have similar technological achievement level (Todaro \& Smith, 2006). Later on, Romer presented the concept of knowledge as a factor to increase the economic growth which provided foundation for the new theoretical concept for analyzing the economic growth factors; known as endogenous growth model (Romer, 1986, 1987). In this context, there are many studies which attempt to explain the nexus between R\&D expenditure and economic growth.

The analysis and measurement of the impact of R\&D investment on economic growth have been one of the most challenging and controversial tasks in empirical studies. The findings of the empirical studies carried out so far, regarding the nexus between R\&D investment and economic growth, have mixed views. Most of the empirical studies have found positive impact of $R \& D$ investment on economic growth and the long-run association between two variables. However, a few studies observed insignificant impact or negative impact of $R \& D$ investment on economic growth, and found no long-run association between these two variables. A large volume of literature is available regarding the impact of R\&D activities on economic growth in developed countries. But the literature regarding the empirical studies that has exclusively discussed the impact of R\&D investment on economic growth in developing countries is rare.

Hall (1996) examined that R\&D investments are positively correlated with the company's productivity and profitability, resulting in relatively high private returns. Grossman and Helpman (1991) and Aghion and Howitt (1992, 1998) discussed the characteristics of technological progress in their studies and revealed that investment on R\&D influences the economic growth positively. Lichtenberg (1992) examined the impact of R\&D expenditure on economic growth by using the data of 74 countries from 1964 to 1989 in the contexts of private and public sectors. He found the positive impact of $R \& D$ investment on growth, but he advocated that private $R \& D$ investment is observed to be more effective and efficient than public sector investment. Zhang (1993) presented a model to examine the dynamic process of knowledge and capital accumulation, price structure and explored the nexus between public sector research, universities and economic growth. He indicated the existence of a long run equilibrium. Coe, Helpman and Hoffmaister (1997) treated the R\&D expenditure as externalities between developing and developed countries and calculated the spill over effect of R\&D investment in developed countries to developing countries. They argued that R\&D investment in the developed countries not only influences the national income positively but the economies of developing countries also benefit from this investment through the import of high-technology goods from developed economies; resultantly the high-technology capital goods enhance the efficiency improvement in developing countries. They concluded that rise in R\&D investment in industrial economies positively and significantly affect outputs of developing economies (Coe, Helpman \& Hoffmaister, 1997). Keller (1998) re-examined the impact of R\&D expenditure on growth of total factor productivity (TFP) in developing economies and raised some questions about the verdict of Coe, Helpman and Hoffmaister (1997).

Segerstrom (2000) explained the effect of R\&D subsidies on economic growth in the long-run without scale effect. He argued that R\&D subsidies may either hinder or enhance the economic growth in the long-run. Freire-Sern (2001) investigated the relative significance of aggregate R\&D investment to economic growth by introducing an innovative technology. He emphasized on long-run growth rate as a result of accumulation of physical capital and R\&D investment 
subsidies. He argued that subsidies on R\&D investment and physical capital would enhance the innovation activity. He proved the positive relationship between growth and physical capital subsidy as it accelerates the increment in various capital goods. He indicated a strong positive association between the variables and revealed that $1 \%$ increase in $\mathrm{R} \& \mathrm{D}$ investment leads to $0.08 \%$ increase in the real GDP. Van Pottelsberghe and Guellec (2004) examined the effect or R\&D investment on economic growth by utilizing the data of 16 OECD countries and observed a significant and positive effect of R\&D investment on economic growth. Ulku (2004) investigated the nexus between $R \& D$ investment and invention, and consequent effect of innovation on economic growth. He used the data of 20 OECD countries, and by applying various panel data methods, found positive and significant relationship among variables. He observed that $0.17 \%$ increase in inventions caused by $1 \%$ increase in R\&D investment consequently brought about increase in the per capita output of the country, and hence supported the endogenous growth model.

Tiryakioglu (2006) used the data of OECD member countries and found positive causal relationship between $\mathrm{R} \& \mathrm{D}$ expenditure and economic growth by causality analysis. He focused on significance of technology on economic growth and found long-run and short-run relationship between both the variables. Ulku (2007) used the data of 17 OECD countries in different sectors and found that the R\&D enhances the innovation in the chemicals, electrical \& electronics and drugs \& medicine sectors which consequently, positively affects the overall economic growth of the country. Sadraoui and Zina (2009) found active nexuses between R\&D and the economic growth. They used the panel data of 23 countries for the period of 1992 to 2004 and applied the Generalised Moment Method and panel data techniques. Their results revealed that positive and significant relationship exists between $R \& D$ cooperation and economic growth for selected countries. Samimi and Alerasoul (2009) examined the effect of R\&D on economic growth in developing countries. They selected 30 developing countries for which the data was available from 2000 to 2006. They found no significant impact of R\&D expenditure on economic growth in the developing countries. On the contrary to Samimi and Alerasoul (2009), Gocer (2013) observed positive relationship between R\&D expenditures and economic growth in developing countries. He utilized the data of 11 developing Asian economies from 1996 to 2012 and found that $1 \%$ rise in $R \& D$ expenditure leads to increase in modern technology goods and informationcommunication technology exports by $6.5 \%$ and $0.6 \%$ respectively, and consequently enhance the economic growth by $0.43 \%$.

Gene and Atasoy (2010) conducted a study of 34 countries for the period of 1990 to 2010 and by applying different cointegration tests observed positive relationship between R\&D expenditures and economic growth. By applying causality test, They also found that R\&D expenditure veritably encourages economic growth. Bacovic and Bozovic (2010) found significant correlation between R\&D investments and education (as \% of GDP) and resultantly, growth rate of GDP. They investigated that those countries which invest more in knowledge and R\&D achieve higher productivity and GDP growth. They retrieved the data of 29 countries for the period of 2000 to 2006 from EUROSTAT and used the fixed-effect model for estimation. Their results revealed that $1 \%$ increase in R\&D share in GDP leads to a rise of $0.138 \%$ in GDP. They also reported that $1 \%$ rise in public expenditure in education bring about $0.105 \%$ change in GDP per capita.

Poorfaraj et al. (2011) utilized 9 years panel data of 16 developing countries from 2000 to 2008. They used the GDP as dependent variable and knowledge economy index (R\&D, human resources and diffusion of information and communication technology (ICT), investment, general government consumption and labour force as independent variables. Their results showed significant and positive effect of knowledge index on economic growth, and suggested more investment in knowledge (R\&D sector). Gyekye et al. (2012) conducted a study about the subSaharan African countries to investigate the impact of R\&D expenditure and investment on 
economic growth by using the Cobb-Douglas production function approach by using the panel data. They estimated that $1 \%$ rise in $\mathrm{R} \& \mathrm{D}$ expenditure would enhance economic growth by $0.36 \%$, and $1 \%$ increase in investment (gross fixed capital formation) leads to increase the economic growth by $0.26 \%$. García-Manjon \& Romero-Merino (2012) in their study examined the impact of R\&D expenditure of a firm on a firm's growth for a sample of 754 firms from 18 European countries. They applied generalized method of moments (GMM), ordinary least square (OLS) method and quantile regression. They determined that the influence of R\&D expenditure on growth is more substantial in high-technology industries than in low-technology industries.

The question arises that whether R\&D expenditure has a significant impact on the economic growth of developing economies as compared to the developed countries or not? Gumus \& Celikay (2015) try to explore the link between research and development (R \& D) costs and economic growth and find if this link varies with respect to the degree of development of a country. They used the dynamic panel data model for 52 countries from 1996 to 2010. The findings of study revealed that R\&D investment has significant and positive impact on economic growth in the long-run while its effect in developing countries is feeble in short-run and strong in the long-run. Inekwe (2015) investigated the impact of R\&D investment on economic growth for 66 developing countries. He split the countries into two groups as upper-middle-income economies and lower-middle-income economies. He observed positive effect of R\&D investment on economic growth in developing countries and found that the impact of R\&D investment on economic growth is positive in upper-middle-income economies while insignificant in lowermiddle-income economies. He concluded that R\&D investment is favourable to growth. Kaur \& Singh (2016) examined the nexus between R\&D expenditures and per-capita Gross Domestic Product (GDP). They applied random effect and fixed effect models for panel data regression by using the data of 23 developing economies for the period of 1991 to 2010. The estimated coefficient values for these models were 0.28 and 0.30 , showing significant impact of $R \& D$ investment on economic growth. Sokolov-Mladenović, Cvetanović \& Mladenović (2016) explored the effect of R\&D investment on economic growth by constructing a multiple regression model for $28 \mathrm{EU}$ countries covering the period from 2002 to 2012. They found that $1 \%$ rise in $\mathrm{R} \& \mathrm{D}$ expenditure tends to increase real GDP growth by $2.2 \%$. They also reflected the real financial crises and stress upon the negative impact of fertility on economic growth in EU28 countries.

Summarizing the literature review, it is stated that although we attempted to focus on the developing countries, but studies that used OECD data to examine the empirical association between R\&D investment and economic growth have also to be included as they were dominating the available literature. Some important studies i.e. Sylwester (2001), Sarac (2009), Freire-Seren (1999) and Gulmez and Yardimcioglu (2012) are worth mentioning. They used different data sets of OECD countries but produced almost similar results. Sylwester (2001) used data from 20 OECD countries and found no relationship between variables. While Sarac (2009) used the data of 10 OECD countries, and Freire-Seren (1999) and Gulmez and Yardimcioglu (2012) employed the data of 21 OECD countries and found a positive relationship between R\&D expenditure and economic growth. In case of developing countries, similar situation is found. Samimi and Alerasoul (2009) found negative relationship between R\&D expenditure and economic growth by using the data of 30 developing countries while Inekwe (2015) found that the impact of $\mathrm{R} \& \mathrm{D}$ investment on economic growth is positive in upper middle-income economies and insignificant in lower income economies, and concluded that R\&D investment is favourable to growth. Kaur \& Singh (2016), Gocer (2013), Poorfaraj et al. (2011) and Sadraoui and Zina (2009) have confirmed a positive relationship between R\&D expenditure and economic growth.

Hence, some confusion still exists whether R\&D has an impact on economic growth or not? Is 
the impact of $\mathrm{R} \& \mathrm{D}$ expenditures on economic growth in developing countries similar to the developed countries? The main objective of the present study is to remove this confusion by investigating the impact of $R \& D$ expenditure on economic growth by utilizing a large set of 100 countries, and making comparisons between different groups of countries.

\section{Insight of R\&D Investment (Growth and Trends of R\&D Expenditure)}

Research and Development (R\&D) is the highly recognized metric of innovation in knowledge based economy. The R\&D activities contribute to the development of new inventions, innovations, creations, enhance the knowledge, products and processes and hence are a vital driver of economic growth (OECD, 2002). R\&D is flourished and watered by R\&D investment. Before we discuss that how R\&D investment works. It is necessary to know the trends and actual positions of the regions and countries of the world in R\&D spending. During the last two decades, an increasing trend in the global gross domestic expenditure on research and development has been observed (Figure 1). In 1996 the total GERD of the world was PPP\$ 0.66 billion (in constant price - 2005) which reached up to $\$ 1.5$ billion in 2014 showing an increase of $130 \%$. The growth in total global R\&D spending has been increasing at an average of $6.8 \%$ over the 19 years period from 1995-2014.

Figure 1: Global pattern of gross domestic expenditure on research and development (GERD)*

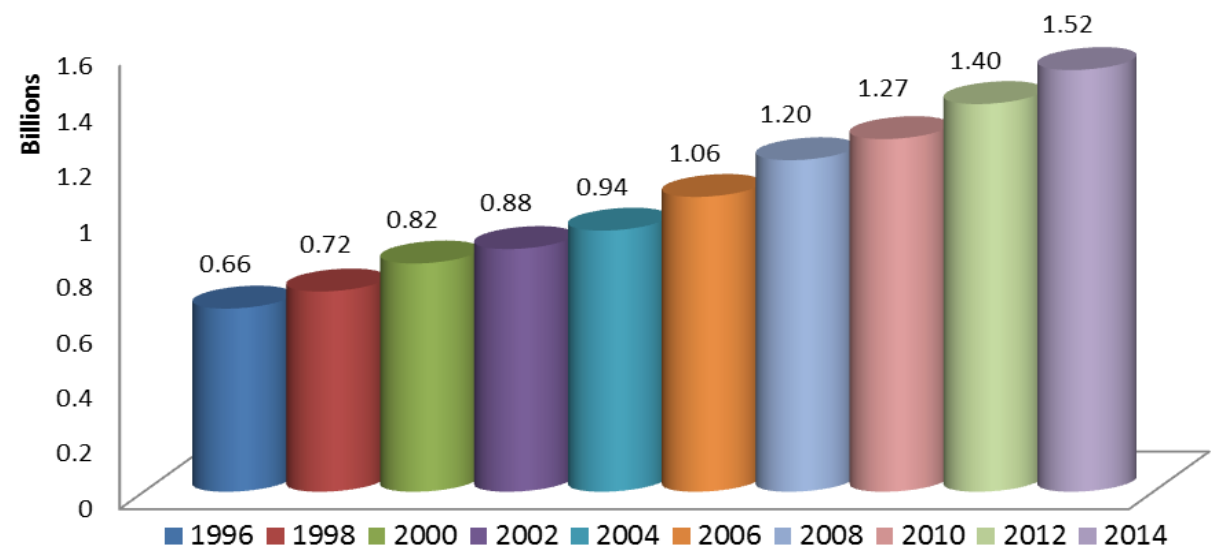

Source: UIS, UNESCO, *GERD in '000 PPP\$ (in constant prices - 2005)

The R\&D investments of different regions are presented in Figure 2. In 1992, North America and Western Europe (USA, Canada, France, Germany, and Switzerland etc.) contributed 65\% (\$0.431 billion) and East Asia and the Pacific (China, Japan, Korea, and Malaysia etc.) accounted for $25 \%$ of the world R\&D investment. While other regions like Latin America and the Caribbean (4\%), Central and Eastern Europe (4\%), South and West Asia (India, Pakistan, Turkey, Israel etc.) (2\%), Arab States (1\%), Sub-Saharan Africa (1\%) and Central Asia (0.001\%) were not able to participate massively in the world wide R\&D investment (Figure 2a).

But in 2014, East Asia and the Pacific performed very well, and with an increase of $70 \%$ their share in the world R\&D investment reached to 39\%. South and West Asia, with 100\% increase, accounted for $4 \%$ of the world share. North America, and Western Europe, with reduction of $28 \%$, accounted for $47 \%$ of the world share in 2014 (Figure 2b). While other regions of the world remained at the same position in 2014 as in 1995.

Figure 3 shows the comparison of three indicators. Each bubble has three pieces of information related to it; $\mathrm{X}$ coordinate represents GERD as a percentage of GDP, Y coordinate gives researchers per million and bubble size reflects the total R\&D budget in US dollar. It may be noted that the USA has a large size of the circle (Figure 3), indicating the highest R\&D budget ( $\$ 420.50$ million) but behind the position of South Korea in terms of R\&D investment as a 
percentage of GDP (4.23\%) and the number of researchers per million (7087). The performances of East Asian countries (especially Korea, China, and Japan) in all three indicators are better than North America (USA and Canada). South Asian countries, Middle East, and North Africa, Latin America \& the Caribbean countries seem to gather around the origin of $\mathrm{x}$-axis and $\mathrm{y}$-axis as they are weak in all three indicators. European countries are looking better in all three dimensions. Demark (7483), Sweden (7021), and Finland (6816) are on the top for the number of researchers per million but small circles depict their low R\&D budget; they are also behind South Korea in GERD as \% of GDP.

Figure 2: Gross domestic expenditure on research and development (GERD)* of different regions
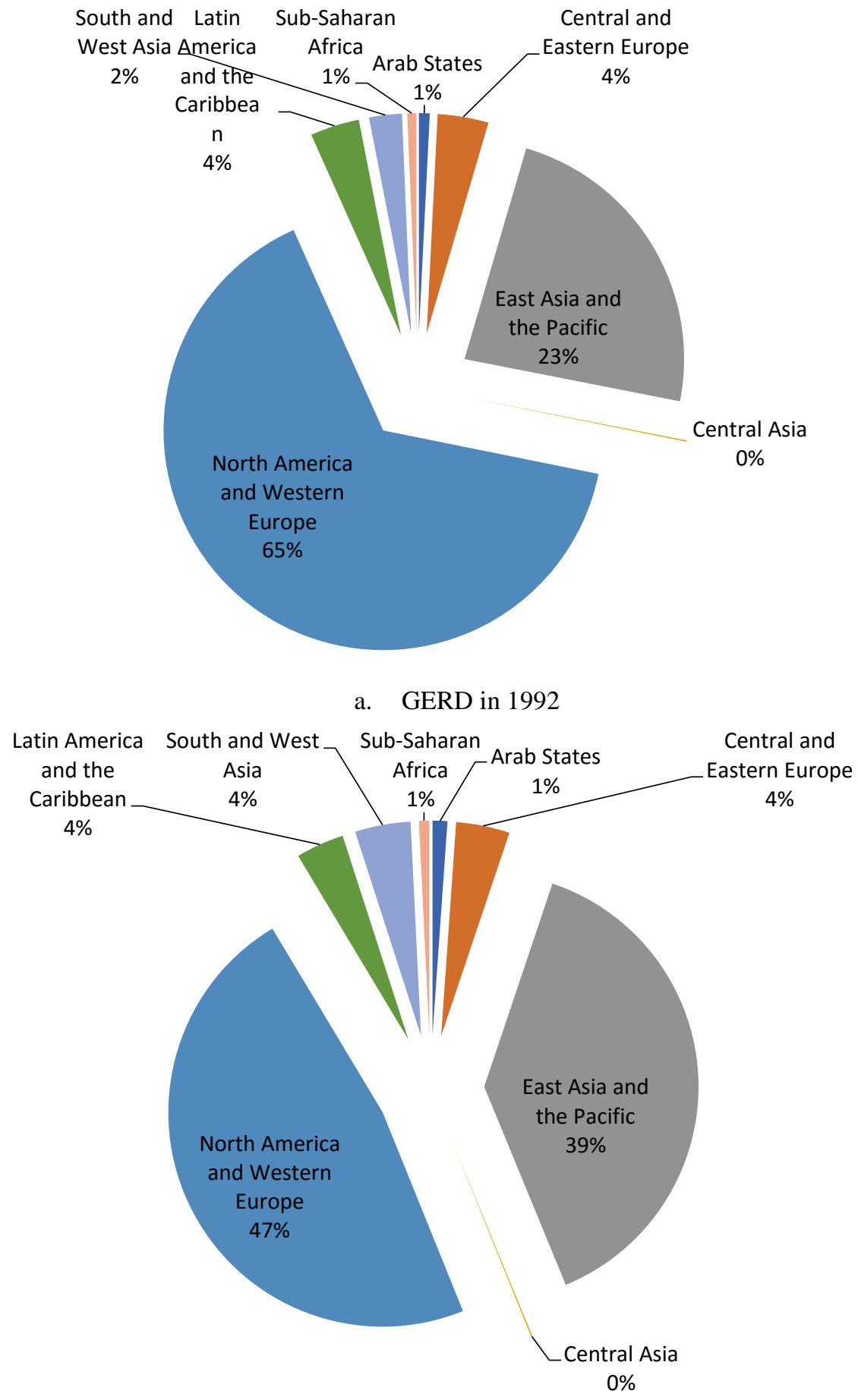

b. GERD in 2014

Source: UIS, UNESCO, *GERD in '000 PPP\$ (in constant price - 2005) 
Figure 3: Relationship between GERD as percentage of GDP and researchers per million inhabitants (FTE) for the year 2015

The circle size indicate the country spending on R\&D in Year 2015

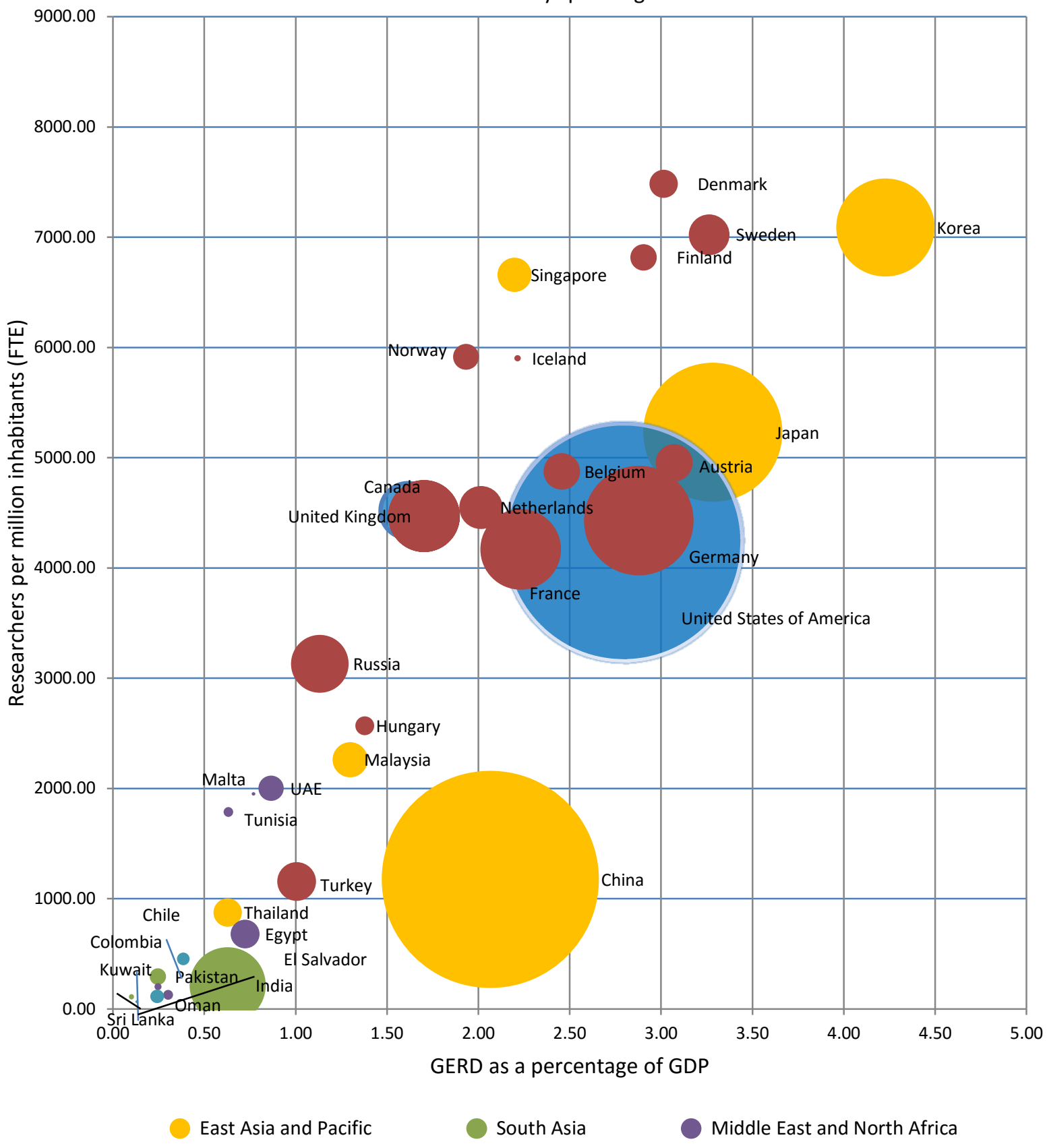

Source: UIS, UNESCO, WDI, World Bank

\section{Growth Rate of GERD}

Annual growth rate of GERD of 73 countries over the period of 20 years from 1996 to 2015 has been calculated and presented in Table 1. The trends of the growth rate of 30 selected countries are presented in Figure 4 which shows negative growth rate for many countries.

Table 1. Annual growth rate of GERD for selected 73 countries (1996-2015)

\begin{tabular}{c|c|c|c|c|c|c|c|c|c|c|c}
\hline $\mathbf{1}$ & $\mathbf{2}$ & $\mathbf{3}$ & $\mathbf{4}$ & $\mathbf{5}$ & $\mathbf{6}$ & $\mathbf{7}$ & $\mathbf{8}$ & $\mathbf{9}$ & $\mathbf{1 0}$ & $\mathbf{1 1}$ & $\mathbf{1 2}$ \\
\hline S\# & Country & $\mathbf{1 9 9 6 -}$ & $\mathbf{1 9 9 7 -}$ & $\mathbf{1 9 9 8 -}$ & $\mathbf{1 9 9 9 -}$ & $\mathbf{2 0 0 0 -}$ & $\mathbf{2 0 0 1 -}$ & $\mathbf{2 0 0 2 -}$ & $\mathbf{2 0 0 3 -}$ & $\mathbf{2 0 0 4 -}$ & $\mathbf{2 0 0 5 -}$ \\
& & $\mathbf{9 7}$ & $\mathbf{9 8}$ & $\mathbf{9 9}$ & $\mathbf{0 0}$ & $\mathbf{0 1}$ & $\mathbf{0 2}$ & $\mathbf{0 3}$ & $\mathbf{0 4}$ & $\mathbf{0 5}$ & $\mathbf{0 6}$ \\
\hline 1 & Argentina & 8.65 & 1.80 & 6.49 & -3.97 & -7.51 & -18.40 & 14.79 & 7.34 & 13.04 & 16.15 \\
\hline 2 & Australia & -0.53 & -0.53 & 6.75 & 6.33 & 8.87 & 8.15 & 6.74 & 6.32 & 12.58 & 11.17
\end{tabular}




\begin{tabular}{|c|c|c|c|c|c|c|c|c|c|c|c|}
\hline 3 & Austria & 6.99 & 8.40 & 10.34 & 5.62 & 7.05 & 5.42 & 6.24 & 2.28 & 11.99 & 2.83 \\
\hline 4 & Azerbaijan & 66.12 & 25.40 & 0.17 & -4.99 & 11.21 & -1.91 & 19.83 & 1.16 & -6.80 & 4.97 \\
\hline 5 & Belarus & -18.56 & 4.80 & 23.83 & -9.61 & 2.79 & -7.98 & 5.42 & 14.39 & 18.28 & 7.10 \\
\hline 6 & Belgium & 7.62 & 3.62 & 7.37 & 5.37 & 6.02 & -4.81 & -2.36 & 2.34 & 0.59 & 4.34 \\
\hline 7 & Brazil & $\ldots$ & $\ldots$ & $\ldots$ & $\ldots$ & 4.75 & -2.40 & 3.41 & 1.96 & 7.38 & 2.47 \\
\hline 8 & Bulgaria & -8.52 & 8.98 & 3.29 & -3.37 & -6.25 & 10.11 & 6.85 & 6.15 & 0.74 & 6.69 \\
\hline 9 & Canada & 4.74 & 10.12 & 7.58 & 11.70 & 10.70 & 0.49 & 1.60 & 4.62 & 1.83 & 1.13 \\
\hline 10 & Chile & $\ldots$ & $\ldots$ & $\ldots$ & $\ldots$ & $\ldots$ & $\ldots$ & $\ldots$ & $\ldots$ & $\ldots$ & $\ldots$ \\
\hline 11 & China & 23.87 & 9.22 & 24.77 & 29.26 & 14.06 & 22.77 & 16.54 & 19.41 & 19.92 & 17.94 \\
\hline 12 & Hong Kong & $\ldots$ & $\ldots$ & 9.54 & 9.37 & 16.03 & 10.19 & 20.57 & 15.33 & 15.08 & 9.97 \\
\hline 13 & Macao & $\ldots$ & $\ldots$ & $\ldots$ & $\ldots$ & $\ldots$ & 21.73 & 0.17 & 8.39 & 77.16 & 7.24 \\
\hline 14 & Colombia & -5.41 & -17.40 & -21.07 & -26.70 & 3.11 & 8.42 & 16.27 & 3.66 & 2.22 & 5.79 \\
\hline 15 & Costa Rica & 3.27 & -4.05 & 43.94 & 16.09 & -0.65 & -0.65 & -0.65 & 7.50 & 13.80 & 12.13 \\
\hline 16 & Croatia & $\ldots$ & $\ldots$ & $\ldots$ & 28.92 & -9.21 & 8.88 & 5.83 & 12.87 & -13.54 & -9.36 \\
\hline 17 & Cuba & 18.87 & 24.97 & -2.90 & 10.62 & 21.86 & 1.28 & 7.10 & 9.38 & 1.40 & -9.93 \\
\hline 18 & Cyprus & $\ldots$ & $\ldots$ & 12.34 & 9.07 & 8.55 & 21.92 & 18.43 & 9.83 & 12.52 & 8.92 \\
\hline 19 & Congo DR & $\ldots$ & $\ldots$ & $\ldots$ & $\ldots$ & $\ldots$ & $\ldots$ & $\ldots$ & $\ldots$ & -77.02 & 10.98 \\
\hline 20 & Denmark & 7.97 & 8.55 & 9.18 & 7.14 & 6.67 & 5.51 & 3.24 & -1.06 & 1.26 & 4.22 \\
\hline 21 & Ecuador & -11.77 & 7.45 & $\ldots$ & $\ldots$ & $\ldots$ & 11.88 & 6.45 & 55.60 & 35.73 & 26.33 \\
\hline 22 & Egypt & -1.97 & 4.85 & -0.60 & 8.74 & 14.92 & 12.98 & 11.49 & 10.31 & -6.57 & 14.64 \\
\hline 23 & El Salvador & $\ldots$ & $\ldots$ & . & $\ldots$ & $\ldots$ & $\ldots$ & $\ldots$ & $\ldots$ & $\ldots$ & $\ldots$ \\
\hline 24 & Finland & 13.62 & 11.99 & 14.54 & 12.19 & 1.07 & 3.57 & 3.39 & 4.33 & 3.24 & 4.30 \\
\hline 25 & France & -1.16 & 1.07 & 4.04 & 3.23 & 4.16 & 2.86 & -1.72 & 1.58 & -0.43 & 2.42 \\
\hline 26 & Germany & 3.83 & 3.55 & 7.59 & 5.51 & 1.44 & 1.25 & 0.98 & -0.30 & 0.78 & 5.13 \\
\hline 27 & Greece & $\ldots$ & 20.90 & 17.29 & 3.27 & 3.17 & 3.70 & 3.57 & 1.36 & 10.45 & 2.41 \\
\hline 28 & Guatemala & & $\ldots$ & & & $\ldots$ & & $\ldots$ & $\ldots$ & ‥ & 48.43 \\
\hline 29 & Hungary & 14.56 & -2.18 & 5.42 & 22.70 & 19.90 & 12.53 & -2.80 & -1.60 & 11.78 & 10.66 \\
\hline 30 & Iceland & $\ldots$ & 16.47 & 19.55 & 21.14 & 14.80 & 0.16 & -1.99 & 6.48 & 6.08 & 12.99 \\
\hline 31 & India & 11.81 & 8.83 & 11.99 & 8.55 & 1.90 & 2.36 & 6.91 & 13.57 & 19.07 & 7.48 \\
\hline 32 & Iran & $\ldots$ & $\ldots$ & $\ldots$ & $\ldots$ & $\ldots$ & 6.66 & 30.40 & -8.45 & 28.09 & -5.14 \\
\hline 33 & Iraq & $\ldots$ & $\ldots$ & $\ldots$ & $\ldots$ & $\ldots$ & $\ldots$ & $\ldots$ & $\ldots$ & $\ldots$ & $\ldots$ \\
\hline 34 & Ireland & 8.39 & 5.26 & 5.65 & 3.49 & 2.95 & 5.87 & 10.39 & 11.86 & 7.02 & 6.34 \\
\hline 35 & Israel & 12.71 & 8.34 & 18.15 & 28.73 & 6.70 & -1.34 & -4.51 & 4.45 & 8.82 & 8.13 \\
\hline 36 & Italy & 6.29 & 3.45 & -0.91 & 6.04 & 5.77 & 4.08 & -1.96 & 0.73 & 0.37 & 5.89 \\
\hline 37 & Japan & 3.99 & 2.58 & 0.41 & 3.24 & 2.69 & 1.54 & 2.51 & 1.75 & 6.75 & 4.53 \\
\hline 38 & Kazakhstan & $\ldots$ & -26.31 & -14.34 & 8.13 & 37.98 & 27.26 & 8.17 & 7.82 & 25.26 & -5.22 \\
\hline 39 & Kuwait & $\ldots$ & 30.19 & -24.75 & -33.56 & 43.61 & 3.69 & -6.50 & 0.44 & -14.69 & -9.59 \\
\hline 40 & Latvia & 0.52 & 10.12 & -4.67 & 30.61 & -1.54 & 8.61 & -4.53 & 20.41 & 46.51 & 37.46 \\
\hline 41 & Lithuania & 18.21 & 8.91 & -8.73 & 20.96 & 21.46 & 5.14 & 11.67 & 20.57 & 7.26 & 13.70 \\
\hline 42 & Luxembourg & $\ldots$ & $\ldots$ & $\ldots$ & $\ldots$ & 4.20 & 4.03 & 3.87 & 2.70 & 1.23 & 11.68 \\
\hline 43 & Malaysia & 41.38 & 29.27 & 18.09 & 15.32 & 23.70 & 19.16 & 1.93 & 1.89 & 6.64 & 6.23 \\
\hline 44 & Mexico & 18.67 & 15.29 & 15.55 & -6.35 & 6.14 & 12.94 & 3.33 & 5.70 & 5.48 & -2.98 \\
\hline 45 & Netherlands & 4.56 & -1.14 & 9.74 & 2.11 & 2.69 & -2.47 & 2.36 & 2.13 & 1.24 & 1.53 \\
\hline 46 & $\begin{array}{l}\text { New } \\
\text { Zealand }\end{array}$ & $\ldots$ & -1.58 & -1.60 & 10.67 & 9.64 & 7.29 & 6.80 & 2.34 & 2.29 & 4.64 \\
\hline 47 & Norway & $\ldots$ & 2.73 & 2.66 & 1.27 & 1.25 & 5.87 & 4.00 & -4.41 & -1.49 & 0.52 \\
\hline 48 & Pakistan & & -28.06 & 10.03 & 15.40 & 32.53 & 36.08 & 46.98 & 31.96 & 24.22 & 30.57 \\
\hline 49 & Panama & 2.69 & -3.38 & 5.01 & 36.92 & 0.05 & -3.03 & -2.22 & -24.16 & 9.73 & 10.31 \\
\hline 50 & Peru & $\ldots$ & 20.01 & -0.76 & 17.47 & -0.90 & 0.87 & 6.11 & 51.21 & $\ldots$ & $\ldots$ \\
\hline
\end{tabular}

Table 1.Contd...

\begin{tabular}{c|l|c|c|c|c|c|c|c|c|c|c}
\hline 1 & 2 & 3 & 4 & 5 & 6 & 7 & 8 & 9 & 10 & 11 & 12 \\
\hline S\# & Country & $1996-$ & $1997-$ & $1998-$ & $1999-$ & $2000-$ & $2001-$ & $2002-$ & $2003-$ & $2004-$ & $2005-$ \\
\hline
\end{tabular}




\begin{tabular}{c|l|c|c|c|c|c|c|c|c|c|c}
\hline & & $\mathbf{9 7}$ & $\mathbf{9 8}$ & $\mathbf{9 9}$ & $\mathbf{0 0}$ & $\mathbf{0 1}$ & $\mathbf{0 2}$ & $\mathbf{0 3}$ & $\mathbf{0 4}$ & $\mathbf{0 5}$ & $\mathbf{0 6}$ \\
\hline 51 & Philippines & $\ldots$ & $\ldots$ & $\ldots$ & $\ldots$ & $\ldots$ & $\ldots$ & -0.75 & -2.07 & -2.11 & 5.20 \\
\hline 52 & Poland & 7.08 & 7.33 & 7.96 & -1.54 & -1.78 & -8.61 & 0.03 & 7.80 & 5.42 & 3.92 \\
\hline 53 & Portugal & 7.11 & 16.15 & 13.26 & 9.92 & 8.06 & -4.91 & -4.21 & 6.35 & 4.69 & 28.04 \\
\hline 54 & Korea & 7.87 & -11.36 & 6.27 & 15.07 & 12.24 & 4.35 & 6.45 & 12.97 & 7.77 & 13.37 \\
\hline 55 & Romania & -19.01 & -15.51 & -19.89 & -5.71 & 12.47 & 1.97 & 7.51 & 8.26 & 10.81 & 19.66 \\
\hline 56 & Russia & 9.57 & -13.46 & 11.13 & 15.92 & 17.81 & 11.05 & 10.58 & -4.05 & -1.33 & 8.66 \\
\hline & Saudi & & & & & & & & & & \\
57 & Arabia & $\ldots$ & $\ldots$ & $\ldots$ & $\ldots$ & $\ldots$ & $\ldots$ & $\ldots$ & -7.37 & -14.63 & 5.95 \\
\hline 58 & Serbia & $\ldots$ & 8.86 & 9.32 & -2.95 & -62.45 & 126.62 & -19.89 & -36.33 & 44.51 & 17.47 \\
\hline 59 & Singapore & 16.23 & 20.05 & 10.91 & 9.21 & 9.88 & 6.65 & 2.33 & 13.78 & 10.35 & 7.48 \\
\hline 60 & Slovenia & 3.53 & 8.18 & 7.83 & 5.57 & 11.41 & 1.78 & -10.99 & 14.64 & 7.37 & 14.68 \\
\hline & South & & & & & & & & & & \\
61 & Africa & $\ldots$ & 8.77 & 8.06 & 7.46 & 6.94 & 6.71 & 6.29 & 11.82 & 11.72 & 9.87 \\
\hline 62 & Spain & 2.40 & 13.86 & 3.20 & 10.85 & 4.62 & 10.95 & 9.87 & 4.81 & 9.44 & 11.44 \\
\hline 63 & Sudan & $\ldots$ & $\ldots$ & $\ldots$ & -5.15 & 0.66 & -5.90 & -7.34 & -9.56 & 8.43 & $\ldots$ \\
\hline 64 & Sweden & $\ldots$ & 6.15 & 5.80 & 10.84 & 9.78 & -1.74 & -1.77 & -2.12 & 2.69 & 8.19 \\
\hline 65 & Thailand & -16.65 & 67.43 & 40.27 & 2.92 & 6.66 & -3.00 & 14.06 & 3.23 & -4.29 & 11.60 \\
\hline 66 & Trinidad & 20.49 & 19.00 & 4.43 & -5.50 & 0.47 & 36.55 & -0.13 & 7.39 & 6.11 & -28.37 \\
\hline 67 & Tunisia & $\ldots$ & $\ldots$ & $\ldots$ & $\ldots$ & $\ldots$ & $\ldots$ & 25.41 & 19.39 & 0.80 & 0.12 \\
\hline 68 & Turkey & 17.13 & -22.81 & 21.83 & 9.38 & 5.86 & 3.83 & -3.31 & 17.33 & 23.61 & 4.93 \\
\hline 69 & Ukraine & $\ldots$ & -11.97 & -9.55 & 5.08 & 16.14 & 2.62 & 21.85 & 9.05 & -2.10 & -1.22 \\
\hline 70 & UK & 0.27 & 4.21 & 8.60 & 2.59 & 2.26 & 2.89 & 1.06 & -0.66 & 4.30 & 3.96 \\
\hline 71 & USA & 5.73 & 5.54 & 6.57 & 7.32 & 1.66 & -1.63 & 2.94 & 1.23 & 4.01 & 4.47 \\
\hline 72 & Uruguay & 43.34 & -42.69 & 14.57 & -8.46 & 0.49 & 0.49 & 20.41 & 16.95 & 14.49 & 12.66 \\
\hline 73 & Uzbekistan & $\ldots$ & $\ldots$ & $\ldots$ & $\ldots$ & -0.19 & -11.62 & -4.72 & 8.50 & -6.06 & 1.21 \\
\hline
\end{tabular}

Table 1.Contd....

\begin{tabular}{c|l|c|c|c|c|c|c|c|c|c}
\hline $\mathbf{1}$ & $\mathbf{2}$ & $\mathbf{1 3}$ & $\mathbf{1 4}$ & $\mathbf{1 5}$ & $\mathbf{1 6}$ & $\mathbf{1 7}$ & $\mathbf{1 8}$ & $\mathbf{1 9}$ & $\mathbf{2 0}$ & $\mathbf{2 1}$ \\
\hline S\# & Country & $\mathbf{2 0 0 5 - 0 7}$ & $\mathbf{2 0 0 7 - 0 8}$ & $\mathbf{2 0 0 8 - 0 9}$ & $\mathbf{2 0 0 9 - 1 0}$ & $\mathbf{2 0 1 0 - 1 1}$ & $\mathbf{2 0 1 1 - 1 2}$ & $\mathbf{2 0 1 2 - 1 3}$ & $\mathbf{2 0 1 3 - 1 4}$ & $\mathbf{2 0 1 4 - 1 5}$ \\
\hline 1 & Argentina & 10.91 & 6.48 & 17.23 & 5.94 & 7.11 & 11.07 & -0.19 & -7.47 & $\ldots$ \\
\hline 2 & Australia & 9.21 & 8.43 & 1.54 & 1.51 & -3.54 & 1.89 & 1.86 & -100.00 & $\ldots$ \\
\hline 3 & Austria & 6.30 & 7.94 & -2.76 & 6.78 & 0.70 & 10.03 & 1.45 & 3.67 & 1.49 \\
\hline 4 & Azerbaijan & 23.89 & 7.83 & 65.08 & -8.28 & -3.43 & 5.30 & 2.96 & 1.28 & 7.13 \\
\hline 5 & Belarus & 58.14 & -15.07 & -13.15 & 16.26 & 6.62 & -3.14 & 2.06 & -20.95 & -5.10 \\
\hline 6 & Belgium & 5.10 & 5.12 & 0.82 & 6.08 & 6.99 & 9.75 & 3.09 & 2.77 & 1.13 \\
\hline 7 & Brazil & 16.09 & 9.73 & -1.04 & 11.50 & 2.16 & 0.89 & 9.42 & -2.48 & $\ldots$ \\
\hline 8 & Bulgaria & 3.72 & 10.34 & 6.49 & 13.82 & -3.86 & 13.74 & 5.88 & 26.87 & 24.69 \\
\hline 9 & Canada & -0.04 & -1.55 & 0.28 & -1.42 & 0.91 & 1.50 & -3.74 & -2.18 & $\ldots$ \\
\hline 10 & Chile & $\ldots$ & 24.75 & -6.87 & -0.81 & 13.02 & 8.85 & 11.31 & -1.48 & 4.47 \\
\hline 11 & China & 14.60 & 15.38 & 25.86 & 13.82 & 13.73 & 15.78 & 12.53 & 8.97 & 9.34 \\
\hline 12 & Hong Kong & 0.69 & -2.17 & 4.78 & 3.46 & 0.82 & 2.61 & 3.50 & 4.15 & 5.40 \\
\hline 13 & Macao & -21.54 & 83.79 & -45.79 & 15.99 & 7.42 & 18.16 & 18.34 & 68.20 & 22.21 \\
\hline 14 & Colombia & 27.33 & 12.82 & -0.02 & 3.79 & 14.25 & 12.05 & 30.98 & -4.14 & -0.57 \\
\hline 15 & Costa Rica & -9.64 & 13.38 & 32.68 & -2.18 & 0.63 & 24.56 & 2.19 & 6.66 & $\ldots$ \\
\hline 16 & Croatia & 12.56 & 13.89 & -11.56 & -13.29 & 0.75 & -2.35 & 7.43 & -3.49 & 9.86 \\
\hline 17 & Cuba & 5.99 & 19.50 & 24.60 & 1.19 & -54.00 & 54.25 & 19.71 & $\ldots$ & $\ldots$ \\
\hline 18 & Cyprus & 10.66 & 0.67 & 13.09 & 1.82 & 1.18 & -7.99 & 1.66 & 1.88 & -3.17 \\
\hline 19 & Congo DR & 142.08 & -35.11 & -3.39 & $\ldots$ & $\ldots$ & $\ldots$ & $\ldots$ & $\ldots$ & $\ldots$ \\
\hline 20 & Denmark & 5.54 & 9.73 & 4.81 & -2.76 & 2.16 & 1.09 & 0.10 & -0.06 & 2.65 \\
\hline 21 & Ecuador & 4.82 & 83.62 & 74.22 & 5.71 & -9.01 & 3.30 & 19.96 & 20.50 & $\ldots$ \\
\hline 22 & Egypt & 5.47 & 13.51 & 67.78 & 5.22 & 24.86 & -1.07 & 27.93 & 2.28 & 16.76 \\
\hline 23 & El Salvador & $\ldots$ & 27.46 & -33.29 & -12.00 & -52.69 & -0.11 & 92.57 & 48.69 & 57.75 \\
\hline 24 & Finland & 5.44 & 6.78 & -3.05 & 2.36 & 0.17 & -7.37 & -4.60 & -4.22 & -8.27 \\
\hline 25 & France & 1.10 & 2.06 & 4.21 & 0.40 & 2.81 & 1.94 & 1.03 & 0.64 & 0.87 \\
\hline
\end{tabular}


Table 1.Contd...

\begin{tabular}{|c|c|c|c|c|c|c|c|c|c|c|}
\hline 1 & 2 & 13 & 14 & 15 & 16 & 17 & 18 & 19 & 20 & 21 \\
\hline S\# & Country & 2005-07 & 2007-08 & 2008-09 & 2009-10 & 2010-11 & 2011-12 & 2012-13 & 2013-14 & 2014-15 \\
\hline 26 & Germany & 2.85 & 7.31 & -0.92 & 3.59 & 6.79 & 3.10 & -1.16 & 4.02 & 1.24 \\
\hline 27 & Greece & 6.10 & 14.41 & -9.54 & -9.59 & 2.04 & -3.49 & 12.21 & 3.49 & 14.30 \\
\hline 28 & Guatemala & 43.92 & -4.23 & -10.17 & -19.08 & 15.27 & -4.35 & & & \\
\hline 29 & Hungary & -2.00 & 3.28 & 8.02 & 1.36 & 6.14 & 4.50 & 12.22 & 1.58 & 4.38 \\
\hline 30 & Iceland & -3.54 & 0.10 & -0.29 & -3.85 & -4.00 & -12.61 & -14.43 & 16.51 & 13.41 \\
\hline 31 & India & 11.11 & 10.50 & 5.61 & 7.35 & 7.82 & -0.44 & -0.44 & -0.45 & -0.45 \\
\hline 32 & Iran & $\ldots$ & & -56.63 & 4.00 & 6.73 & 6.31 & $\ldots$ & $\ldots$ & \\
\hline 33 & Iraq & $\ldots$ & -18.35 & 37.27 & -14.06 & 1.47 & $\ldots$ & $\ldots$ & $\ldots$ & 0.09 \\
\hline 34 & Ireland & 6.81 & 7.70 & 10.81 & 1.11 & -3.61 & -0.13 & 1.46 & 5.08 & $\ldots$ \\
\hline 35 & Israel & 13.31 & 1.23 & -3.60 & 0.87 & 7.13 & 6.05 & 3.99 & 6.27 & 2.09 \\
\hline 36 & Italy & 5.74 & 1.65 & -0.80 & 1.84 & -0.51 & 2.08 & 1.12 & 5.30 & -2.40 \\
\hline 37 & Japan & 3.55 & -1.17 & -8.42 & 1.15 & 3.31 & 0.38 & 5.37 & 2.95 & -2.20 \\
\hline 38 & Kazakhstan & -6.34 & 7.11 & 7.13 & -28.20 & 7.46 & 12.83 & 9.89 & 1.71 & 2.58 \\
\hline 39 & Kuwait & 7.33 & 2.06 & 21.94 & -11.77 & 7.02 & 4.71 & 213.76 & $\ldots$ & $\ldots$ \\
\hline 40 & Latvia & -6.41 & 1.19 & -33.29 & 29.80 & 21.34 & -0.83 & -5.27 & 14.94 & -6.81 \\
\hline 41 & Lithuania & 12.45 & 1.03 & -10.36 & -4.02 & 22.39 & 2.78 & 9.99 & 12.04 & 2.45 \\
\hline 42 & Luxembourg & 3.41 & 1.29 & -1.54 & -5.62 & 0.41 & -14.56 & 5.41 & 2.99 & 4.83 \\
\hline 43 & Malaysia & 22.94 & 18.66 & 24.86 & 9.74 & 5.02 & 11.52 & 14.13 & 12.38 & 8.18 \\
\hline 44 & Mexico & 18.90 & 11.93 & 4.39 & 8.48 & 0.00 & -0.57 & 3.56 & 9.07 & 5.23 \\
\hline 45 & Netherlands & -0.45 & -0.91 & -1.29 & 3.77 & 12.17 & 0.83 & 0.49 & 3.94 & 2.64 \\
\hline 46 & $\begin{array}{l}\text { New } \\
\text { Zealand }\end{array}$ & 4.44 & 3.15 & 3.05 & 1.05 & 1.04 & -0.69 & -0.70 & -100.00 & \\
\hline 47 & Norway & 10.62 & -0.21 & 9.03 & -3.66 & -0.46 & 2.29 & 3.00 & 5.80 & 14.60 \\
\hline 48 & Pakistan & 23.41 & -12.96 & -14.89 & -11.65 & -13.19 & -1.93 & -1.97 & -4.04 & -4.21 \\
\hline 49 & Panama & -12.15 & 15.04 & -30.03 & 15.54 & 32.68 & -52.31 & -11.76 & . & $\ldots$ \\
\hline 50 & Peru & $\ldots$ & $\ldots$ & $\ldots$ & $\ldots$ & $\ldots$ & -29.13 & 56.43 & 35.15 & 12.32 \\
\hline 51 & Philippines & 4.94 & 4.75 & 4.54 & 7.40 & 6.89 & 17.18 & 14.66 & $\ldots$ & $\ldots$ \\
\hline 52 & Poland & 9.19 & 11.17 & 13.42 & 12.97 & 8.69 & 19.99 & 0.20 & 11.54 & 11.03 \\
\hline 53 & Portugal & 20.72 & 28.80 & 6.05 & -1.14 & -6.68 & -9.24 & -4.82 & -2.09 & 0.60 \\
\hline 54 & Korea & 11.79 & 7.05 & 6.18 & 12.08 & 11.99 & 10.00 & 6.04 & 6.83 & 1.25 \\
\hline 55 & Romania & 23.28 & 18.43 & -24.52 & -2.86 & 10.24 & -1.53 & -17.04 & 1.97 & 32.19 \\
\hline 56 & Russia & 12.90 & -1.52 & 10.50 & -5.66 & -5.67 & 5.87 & 2.26 & 3.71 & 0.22 \\
\hline 57 & Saudi Arabia & 12.89 & 17.56 & 52.43 & 1165.41 & 11.67 & 2.94 & -4.52 & & \\
\hline 58 & Serbia & 40.69 & 20.55 & 18.26 & -13.57 & -1.31 & 23.93 & -17.79 & 3.96 & 13.28 \\
\hline 59 & Singapore & 19.53 & 14.15 & -18.11 & 7.43 & 13.53 & -3.44 & 5.17 & 12.65 & $\ldots$ \\
\hline 60 & Slovenia & -0.67 & 17.94 & 3.02 & 14.69 & 18.55 & 3.53 & -0.14 & -5.55 & -5.10 \\
\hline 61 & South Africa & 3.57 & 3.81 & -7.36 & -9.12 & 2.93 & 2.09 & 0.85 & $\ldots$ & $\ldots$ \\
\hline 62 & Spain & 9.28 & 7.88 & -1.06 & -0.11 & -2.80 & -5.63 & -3.39 & -1.08 & 2.11 \\
\hline 63 & Sudan & & & $\ldots$ & $\ldots$ & $\ldots$ & $\ldots$ & $\ldots$ & $\ldots$ & \\
\hline 64 & Sweden & -3.79 & 6.73 & -6.42 & -1.19 & 3.72 & 0.70 & 2.00 & -2.37 & 7.98 \\
\hline 65 & Thailand & -9.02 & 3.00 & 14.57 & 33.54 & 25.11 & 17.31 & 14.76 & 10.25 & 33.07 \\
\hline 66 & Trinidad & -14.24 & -46.37 & 76.35 & -12.99 & -15.90 & 10.49 & 36.68 & 46.66 & \\
\hline 67 & Tunisia & 4.86 & 0.15 & 13.85 & 1.14 & 0.69 & 0.10 & 1.27 & 0.41 & -2.55 \\
\hline 68 & Turkey & 30.33 & 1.04 & 11.43 & 8.44 & 10.85 & 9.55 & 6.77 & 9.77 & $\ldots$ \\
\hline 69 & Ukraine & -3.00 & 1.49 & -13.79 & 1.40 & -6.64 & 2.12 & 1.31 & -20.22 & -14.41 \\
\hline 70 & UK & 5.05 & -0.24 & -0.65 & 0.38 & 1.81 & -2.86 & 4.92 & 4.26 & 3.65 \\
\hline 71 & USA & 4.85 & 5.02 & -0.96 & -0.31 & 2.68 & -0.14 & 3.03 & 2.91 & 3.79 \\
\hline 72 & Uruguay & 23.84 & -4.18 & 13.24 & -10.85 & 7.49 & -2.73 & 2.57 & 7.95 & a \\
\hline 73 & Uzbekistan & 6.61 & -2.88 & 13.47 & 4.27 & 8.17 & 12.14 & 5.07 & 8.73 & 16.37 \\
\hline
\end{tabular}

Although, the trend of negative growth rate is found in most of developing countries but this trend can also be observed in many developed countries as well. It is generally anticipated that the impact of R\&D investment would not be negative but during the literature review we found some studies which showed the negative link among R\&D investment and economic growth in developing countries. The major reason for this can be the fact that many developing countries 
such as south Asian countries like India and Pakistan are continuously decreasing their R\&D budget for the last five years while their GDPs are increasing. Definitely, if we have such type of data and run the regression analysis, results cannot show positive relation among $R \& D$ expenditure and GDP.

Figure 4. Trends in growth rates of GERD for selected 30 countries

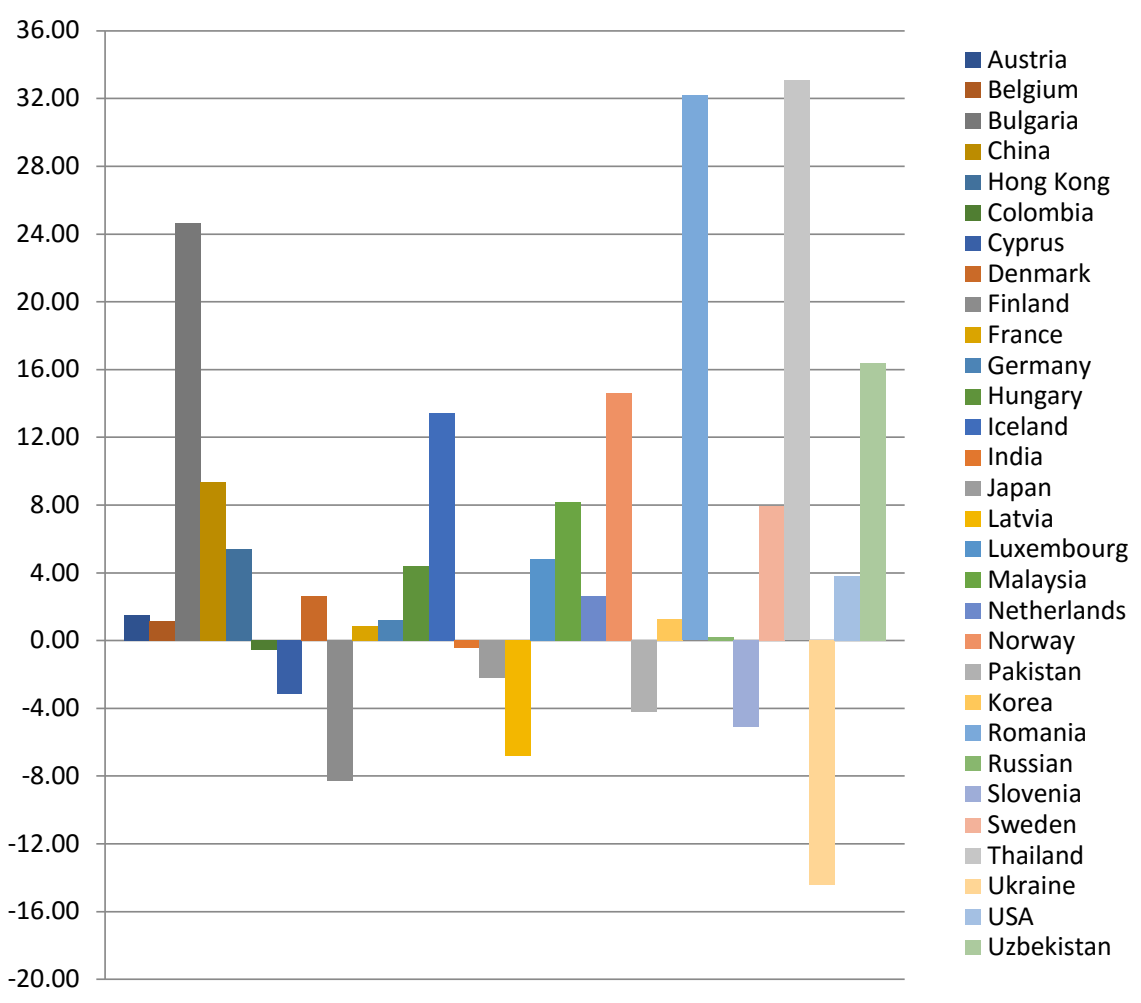

\section{How R\&D Expenditure Works in the Economy}

The nexus between economic growth and the research funded by the government is of greater importance. Although, most of the governments incur large expenditures on research in the organizations, institutions and universities but researchers, scientists, technologists still demand more investment on research. More often the governments have to face the challenge of balancing demands for public funding among different sectors such as education, health, research and other sectors. In these situations, along with other considerations, they may weigh the potential benefits of investing in different sectors. Under consideration this sort of scenario, Salter and Martin (2001) examined the economic benefits gained from government-funded basic research. They argued that to setup the linkage between R\&D expenditure and economic growth, survey, econometric studies and case studies are to be used as the main methodology. Although econometric studies have limitations, they disclose the important economic benefits, the presence of localization and spill over effects. On the basis of their results, they divided the advantages of public expenditure on research into these categories: i) increasing the capacity for technological and scientific problem-solving, ii) creating new scientific methodologies and instrumentation, iii) creation of new firms, iv) stimulating social interaction and forming networks, v) increasing the stock of useful knowledge, and vi) training skilled graduates. The significance of these benefits may vary depending on the nature of the technology, scientific field, and the industrial sector.

The government sector (public funding) in many developing countries is an essential part of the research system. The funds providing agency (like department / ministry of finance) is under control of the government and establishments, despite they (fund providing agency) have no role in the research and the knowledge accumulation process. Park (1998) investigated the role of 
government research in the long-term growth of knowledge spill overs in the industry between transnational research and the private and public research community. He described the scale of government research to maximize the effectiveness of growth. He also said the impact was growing smaller in open economies. In his view, the behaviour of effective government can be avoided when it comes to the parasitic problem of foreign research spill over, and it is interdependent in the accumulation of knowledge at home and abroad.

While allocating the funds for $\mathrm{R} \& \mathrm{D}$, the most common question asked by political leaders or funding agencies, particularly in developing countries is that how much will they contribute to the economy of the country and how? To seek the answers to these questions, the study examines the STI systems of developing countries like Pakistan, India, Sri Lanka etc. and propose the R\&D Diamond Model (Figure 5). The R\&D diamond model describes all the possible channels through which maximum benefits can be achieved by investment in $R \& D$. The universities and $R \& D$ organizations are production house of knowledge in form of patents, publications, skills, creations, inventions, varieties, and discoveries. When, a researcher develops a new invention, creation, patent or variety, he cannot promote or market his product at a big scale in the economy. He needs support from industry for marketization. Industry (textile, Pharmaceutics, electronic, mechanical etc.) takes these inventions and discoveries developed by the researchers and produce them at a large scale and sell them in wider markets; consequently making the whole business profitable.

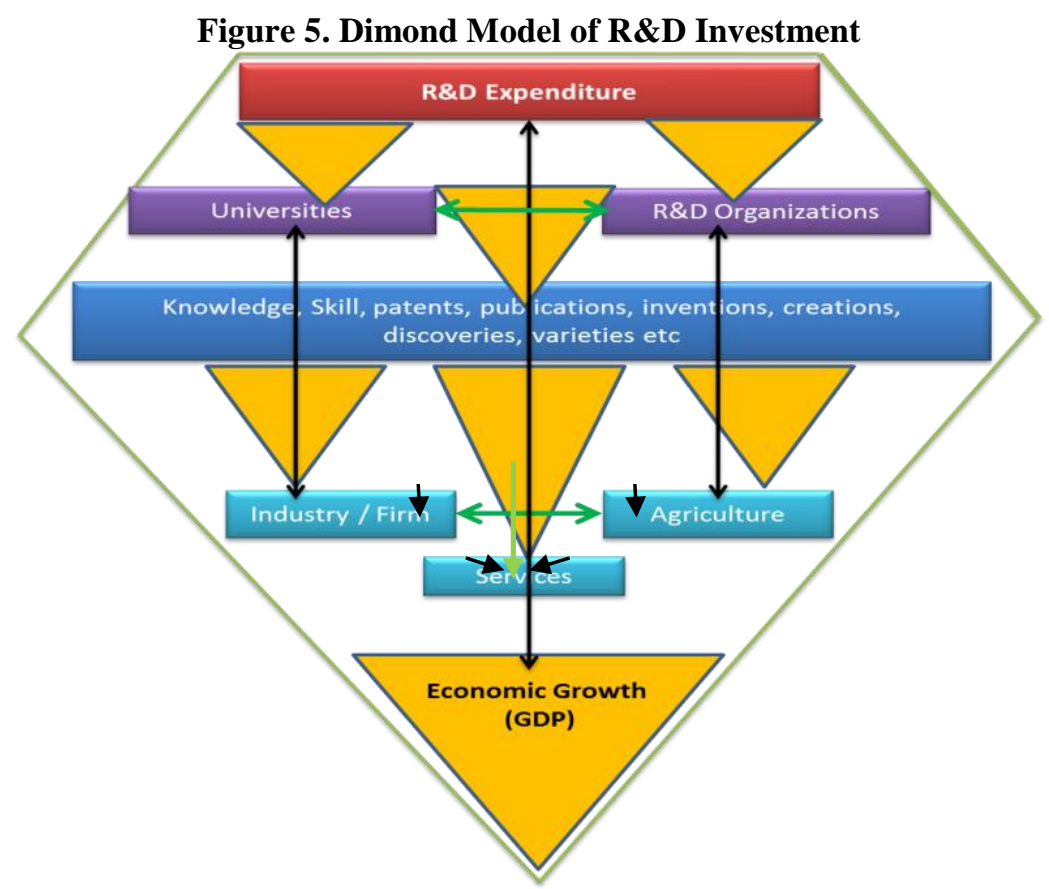

These products would be used to enhance the efficiency of agriculture sector, in result it production would be increased and in retunes agriculture sector provide the raw material for industry, resultantly, the production level of industry would increase as well as the new invention discoveries improve the efficiency of service sector (like health and education sector etc). When the production level of industry and agriculture sector would increase, consequently, it contributes and enhances the GDP of the country or accelerates the economic growth. Therefore, it is dire need to enhance university industry linkage in developing countries. The inter linkages among these five sectors which are depicted in Figure 4 (Universities $\rightarrow$ R\&D Organizations $\rightarrow$ Industry $\rightarrow$ Agriculture $\rightarrow$ Services) would be strong then a country may achieve maximum results of $R \& D$ investment. This whole process needs more than two years. The Impact of R\&D investment on economic growth and society would not be achieved within days or months. It is a long-run phenomenon, not a short-run. 


\section{Measuring the Impact of R\&D Expenditure on Economic Growth The Basic Model \\ Theoretical Frame Work of the Model}

Two types of R\&D based models of endogenous growth are available in the literature. One is the Romer's model, in which different types of inputs are created from research (Romer, 1990 and Baroo, 1997). This model is different from Cobb Douglas production function in which different capital goods were replaced to each other. In Romer's model four types of inputs are used; physical capital, labour force, human capital and technology. The second is Schumpeterian growth model in which old creations or products are outdated by new inventions and innovations (Aghion and Howitt, 1992). Ancient method used to calculate the return to R\&D, depends upon the production function (Hall and Mohnen, 2010).

Arrow (1962) reported that long run economic growth is affected by the technological change endogenously not exogenously, assuming learning by doing, grows at the constant rate and observed that economic growth depends on population growth. In the 1960s, many studies were carried out (Uzawa,1965; Phelps, 1966; Conlisk, 1967 \& 1969 and Shell, 1967) who all related some growth accounting to some specification based on new technologies and other labour resources devoted to the development. Many endogenous growth models have been presented but remarkable studies have been conducted by Romer (1990), Grossman and Helpman (1991) and Aghion and Howitt (1992). All of them focused on the feature that continuous increase in resources spent on the technologies leads to increase in economic growth.

\section{Model Specification}

The study establishes the GDP growth equation in Romer (1990) and Barro (1997):

$$
Y_{t}=F\left(K_{t}, R D_{t}, R P_{t}, L_{M R D P}\right)
$$

Taking long of above equation:

$$
\ln Y_{t}=\alpha+\beta_{1} \ln K_{t}+\beta_{2} \operatorname{lnRD} D_{t}+\beta_{3} \operatorname{lnRDP}_{t}+\beta_{4} \operatorname{lnLMRDP} P_{t}+u_{t}
$$

Where $\alpha$ is constant, $\mathrm{Y}_{\mathrm{t}}$ is Gross Domestic Product, $\mathrm{K}_{\mathrm{t}}$ is Capital, $\mathrm{RD}_{\mathrm{t}}$ is $\mathrm{R} \& \mathrm{D}$ expenditure, $\mathrm{RDP}_{\mathrm{t}}$ is $R \& D$ personal engaged in research activities, and $L_{M R D P}$ is labour force employed minus $\mathrm{R} \& \mathrm{D}$ personal and $\mathrm{u}_{\mathrm{t}}$ is an error term. While Gross Domestic Product (at Constant US Dollar, 2010) and Gross Capital Fixed Formation (GCF) are used as proxy for economic growth $\left(\mathrm{Y}_{\mathrm{t}}\right)$ and Capital $\left(\mathrm{K}_{\mathrm{t}}\right)$.

\section{Data Sources and Estimation Method}

Yearly data for the period ranging from 1995-2015 for top 100 economies have been analysed via simple econometric techniques. EViews10 has been utilized to estimate the above-mentioned models. The data and their sources are given below:

\begin{tabular}{c|c|c}
\hline \multicolumn{1}{c|}{ Variables } & Brief Description & Source \\
\hline $\mathrm{Y}_{\mathrm{t}}(\mathrm{GDP})$ & GDP (constant 2010 US\$) is used as a proxy for economic growth for the country as \\
a dependent variable. & WDI, World Bank \\
\hline $\mathrm{K}_{\mathrm{t}}($ Capital) & Gross capital formation (constant 2010 US\$) is used as proxy for Capital & WDI, World Bank \\
\hline $\mathrm{RD}_{\mathrm{t}}$ & GERD in '000 PPP\$ (in constant prices - 2005) is used as R\&D Expenditure & UIS, UNECO \\
\hline $\mathrm{RDP}_{\mathrm{t}}$ & Total R\&D personnel (FTE) - Total are use as people engaged in R\&D & UIS, UNESCO \\
\hline ELMRDP $_{\mathrm{t}}$ & Employed labour force minus R\&D Personal & WDI, World Bank \\
\hline
\end{tabular}

After formal stationarity testing of the variables, Panel Cointegration is applied to estimate the short-run and long-run relationships between R\&D expenditure and economic growth. Panel ARDL technique has been applied to estimate the influence of R\&D expenditure on economic 
growth. Further, to seek the causal relationship between variables, the Granger Causality test has also been performed.

\section{Empirical Estimation \\ Stationarity Testing}

The most important step of such studies is to determine whether data is stationary or nonstationary. In the present study, stationarity of the variables has been checked by a Panel Unit root test (based on four tests). The results of the Panel Unit root test are presented in Table 2.

TABLE 2. Panel Unit Root Test

\begin{tabular}{|c|c|c|c|c|c|c|}
\hline Variables & Method & $\begin{array}{l}\text { Levin, Lin \& } \\
\text { Chut* }\end{array}$ & $\begin{array}{l}\text { Im, Pesaran } \\
\text { and Shin W- } \\
\text { stat }\end{array}$ & $\begin{array}{l}\text { ADF - } \\
\text { Fisher Chi- } \\
\text { square }\end{array}$ & $\begin{array}{l}\text { PP - Fisher } \\
\text { Chi-square }\end{array}$ & Final Decision \\
\hline \multicolumn{7}{|c|}{$\begin{array}{c}\text { At Level } \\
\text { (Null Hypothesis: Unit Root) }\end{array}$} \\
\hline \multirow{3}{*}{ LY } & Stat $\dagger$ & 1.392 & 8.467 & 83.403 & 92.103 & \multirow{3}{*}{ Non-stationary } \\
\hline & Prob.* & 0.918 & 1.000 & 1.000 & 1.00 & \\
\hline & Decision & Accept & Accept & Accept & Accept & \\
\hline \multirow{3}{*}{ LK } & Stat $\dagger$ & -1.108 & 2.188 & 157.440 & 171.136 & \multirow{3}{*}{ Non-stationary } \\
\hline & Prob.* & 0.133 & 0.985 & 0.967 & 0.858 & \\
\hline & Decision & Accept & Accept & Accept & Accept & \\
\hline \multirow{3}{*}{ LRD } & Stat $\uparrow$ & 5.724 & 9.332 & 93.241 & 94.936 & \multirow{3}{*}{ Non-stationary } \\
\hline & Prob.* & 1.000 & 1.000 & 1.000 & 1.000 & \\
\hline & Decision & Accept & Accept & Accept & Accept & \\
\hline \multirow{3}{*}{ LRDP } & Stat $\uparrow$ & 4.535 & 10.956 & 98.701 & 135.87 & \multirow{3}{*}{ Non-stationary } \\
\hline & Prob.* & 1.000 & 1.000 & 0.999 & 0.875 & \\
\hline & Decision & Accept & Accept & Accept & Accept & \\
\hline \multirow{3}{*}{ LELMRDP } & Stat $\dagger$ & 2.012 & 6.106 & 141.225 & 156.495 & \multirow{3}{*}{ Non-stationary } \\
\hline & Prob.* & 0.977 & 1.000 & 0.999 & 0.989 & \\
\hline & Decision & Accept & Accept & Accept & Accept & \\
\hline \multicolumn{7}{|c|}{$\begin{array}{c}\text { At First Difference } \\
\text { (Null Hypothesis: Unit Root) }\end{array}$} \\
\hline \multirow{3}{*}{$\mathrm{D}(\mathrm{LY})$} & Stat $\dagger$ & -19.252 & -11.829 & 475.358 & 571.681 & \multirow{3}{*}{ Stationary } \\
\hline & Prob.* & 0.000 & 0.000 & 0.000 & 0.000 & \\
\hline & Decision & Reject & Reject & Reject & Reject & \\
\hline \multirow{3}{*}{$\mathrm{D}(\mathrm{LK})$} & Stat $\uparrow$ & -25.613 & -18.897 & 704.481 & 945.843 & \multirow{3}{*}{ Stationary } \\
\hline & Prob.* & 0.000 & 0.000 & 0.000 & 0.000 & \\
\hline & Decision & Reject & Reject & Reject & Reject & \\
\hline \multirow{3}{*}{$\mathrm{D}(\mathrm{LRD})$} & Stat $\uparrow$ & -16.423 & -14.469 & 551.334 & 674.273 & \multirow{3}{*}{ Stationary } \\
\hline & Prob.* & 0.000 & 0.000 & 0.000 & 0.000 & \\
\hline & Decision & Reject & Reject & Reject & Reject & \\
\hline \multirow{3}{*}{ D(LRDP) } & Stat $\dagger$ & -14.925 & -12.295 & 441.256 & 528.579 & \multirow{3}{*}{ Stationary } \\
\hline & Prob.* & 0.000 & 0.000 & 0.000 & 0.000 & \\
\hline & Decision & Reject & Reject & Reject & Reject & \\
\hline \multirow{3}{*}{ D(LELMRDP) } & Stat $\dagger$ & -18.325 & -16.85 & 634.758 & 732.020 & \multirow{3}{*}{ Stationary } \\
\hline & Prob.* & 0.000 & 0.000 & 0.000 & 0.000 & \\
\hline & Decision & Reject & Reject & Reject & Reject & \\
\hline
\end{tabular}

* Probabilities for Fisher tests are computed using an asymptotic Chi-square distribution. All other tests assume asymptotic normality.

$\dagger$ Statistics

The results of all panel root tests clearly indicate that the probability value is greater than $5 \%$ significance level ( $p>.05)$. We, therefore, cannot reject the null hypothesis, and hence, accept that all the series possess a unit root. This indicates that all the time series are integrated order (1) 
and non-stationary. At first difference, however, all the time series are stationary integrated order $(0)$, at a statistically significance level $(\mathrm{p}<.05)$.

\section{Panel Cointegration}

If time series are integrated order (0) at first difference and co-integrated, there may exist a longrun as well as a short-run relationship between variables. To examine the long-run and short-run relations, a panel cointegration test has been used and the results are presented in Table 3.

We have already proved that data is non-stationary at a level and stationary at first difference, which is a precondition of panel cointegration. The results of panel cointegration test are presented in Table 2. There are seven tests and eleven outcomes under the Pedroni residual cointegration test. Significant results were found in five tests out of seven tests. Eight out of eleven outcomes confirmed that cointegration exists between variables. The second test, Kao residual co-integration, also was statistically significant $(\mathrm{p}<.05)$, confirming that cointegration is present. This means that there is a long-run association between $\mathrm{R} \& \mathrm{D}$ investment and economic growth.

TABLE 3. Panel Cointegration Test

\begin{tabular}{|c|c|c|c|c|}
\hline \multicolumn{5}{|c|}{ Pedroni Residual Cointegration Test } \\
\hline \multicolumn{2}{|c|}{ Null Hypothesis: No cointegration } & \multicolumn{3}{|c|}{ Trend assumption: No deterministic trend } \\
\hline \multicolumn{5}{|c|}{ Alternative hypothesis: common AR coefs. (within-dimension) } \\
\hline & Statistic & Prob. & Weighted Statistic & Prob. \\
\hline Panel v-Statistic & 3.091128 & 0.0010 & 2.653262 & 0.0040 \\
\hline Panel rho-Statistic & 6.182482 & 1.0000 & 5.741660 & 1.0000 \\
\hline Panel PP-Statistic & -2.447861 & 0.0072 & -3.571626 & 0.0002 \\
\hline Panel ADF-Statistic & 1.250253 & 0.8944 & -1.789909 & 0.0367 \\
\hline \multicolumn{5}{|c|}{ Alternative hypothesis: individual AR coefs. (between-dimension) } \\
\hline Group rho-Statistic & 8.554568 & 1.0000 & & \\
\hline Group PP-Statistic & -5.958431 & 0.0000 & & \\
\hline $\begin{array}{ll}\text { Group } & \text { ADF- } \\
\text { Statistic } & \end{array}$ & -2.664954 & 0.0038 & & \\
\hline
\end{tabular}

\section{Panel ARDL Models}

Alam and Quazi (2003) argued that panel ARDL approach may be executed even when the explanatory variables are endogenous. Pesaran and Shin (1999) observed that residual correlation and endogeneity may be corrected by using appropriate lags in the model. Panel ARDL method can distinguish between dependent and explanatory variables, while using Engle and Granger cointegration test problem of endogeneity may be faced. Therefore, ARDL model has advantages over the Engle and Granger (1987) approach which is single equation cointegration analysis. Pesaran and Pesaran (1997) explained that the ARDL approach has an extra advantage of returning reliable estimates of the long-run parameters that are asymptotically normal nevertheless whether the variables are I(0), I(1) or mutually integrated. Pedroni (2008) argued that if the data is for more than 20 years it behaves like time series, therefore, the panel ARDL approach is a better option in this case.

The results of stationarity testing and panel cointegration test have confirmed that the entire variables are non-stationary at a level and stationary at first difference and long-run association exists among variables. So, the model fulfills all the prerequisite of the panel ARDL model approach.

Taking into account the above-mentioned facts and advantages, the panel ARDL approach has been preferred in the present study to evaluate the impact of $R \& D$ expenditure on economic growth. The Panel ARDL test is performed on nine different groups of countries. The first group consists of the top100 economies of the world (as per average GDP of 21 years from 1995 to 
2015), including 34 OECD and 66 developing countries. In the second group, 76 countries, including 32 OECD countries and 44 developing countries, for which data of all five variables was available are included. The third group is comprised of 44 developing countries having data of all five variables. For comparative analysis, we divided countries into six groups (three categories):

i. 32 OECD countries Vs 32 Non-OECD countries,

ii. 8 highly developed countries Vs 8 developing countries

iii. 3 East Asian countries Vs 3 South Asian countries

TABLE 4. Estimation of Panel ARDL Model for Groups of 100, 76 and 44 Countries

\begin{tabular}{|c|c|c|c|c|}
\hline Variable & Coefficient & Std. Error & t-Statistic & Prob.* \\
\hline \multicolumn{5}{|c|}{ 1. Group of 100 Countries (66 Developing + 34 OECD) } \\
\hline \multicolumn{5}{|c|}{$\begin{array}{lc}\text { Long Run Equation } \\
\end{array}$} \\
\hline LRD & 0.073 & 0.026 & 2.818 & 0.005 \\
\hline LRDP & 0.023 & 0.031 & 0.734 & 0.463 \\
\hline LK & 0.592 & 0.022 & 26.586 & 0.000 \\
\hline LELMRDP & 0.622 & 0.031 & 19.993 & 0.000 \\
\hline \multicolumn{5}{|c|}{ Short Run Equation } \\
\hline ECT(-1) & -0.001 & 0.008 & -0.088 & 0.027 \\
\hline$\overline{\mathrm{D}(\mathrm{LRD})}$ & 0.257 & 0.188 & 1.367 & 0.172 \\
\hline $\mathrm{D}(\mathrm{LRDP})$ & 0.020 & 0.083 & 0.248 & 0.804 \\
\hline $\mathrm{D}(\mathrm{LK})$ & 0.150 & 0.011 & 13.364 & 0.000 \\
\hline D(LELMRDP) & 0.206 & 0.164 & 1.259 & 0.208 \\
\hline \multicolumn{5}{|c|}{ 2. Group of 76 Countries (44 Developing + 32 Developed (OECD) } \\
\hline \multicolumn{5}{|c|}{$\begin{array}{lc}\text { Long Run Equation } \\
\end{array}$} \\
\hline LRD & 0.116 & 0.020 & 5.700 & 0.000 \\
\hline LRDP & -0.054 & 0.016 & -3.406 & 0.001 \\
\hline LK & 0.898 & 0.022 & 40.673 & 0.000 \\
\hline LELMRDP & 0.017 & 0.011 & 1.629 & 0.104 \\
\hline \multicolumn{5}{|c|}{ Short Run Equation } \\
\hline ECT(-1) & -0.833 & 0.045 & -18.678 & 0.000 \\
\hline $\mathrm{D}(\mathrm{LRD})$ & 0.084 & 0.022 & 3.871 & 0.000 \\
\hline D(LRDP) & -0.028 & 0.015 & -1.832 & 0.067 \\
\hline $\mathrm{D}(\mathrm{LK})$ & 0.028 & 0.041 & 0.690 & 0.490 \\
\hline D(LELMRDP) & 0.051 & 0.010 & 5.121 & 0.000 \\
\hline $\mathrm{C}$ & 2.185 & 0.116 & 18.795 & 0.000 \\
\hline \multicolumn{5}{|c|}{ 3. Group of 44 Developing Countries } \\
\hline \multicolumn{5}{|c|}{ Long Run Equation } \\
\hline LRD & 0.077 & 0.009 & 8.082 & 0.000 \\
\hline LRDP & -0.041 & 0.008 & -5.028 & 0.000 \\
\hline LK & 0.918 & 0.013 & 68.187 & 0.000 \\
\hline LELMRDP & -0.078 & 0.008 & -10.156 & 0.000 \\
\hline \multicolumn{5}{|c|}{ Short Run Equation } \\
\hline ECT(-1) & -1.315 & 0.117 & -11.241 & 0.000 \\
\hline D(LRD) & 0.061 & 0.018 & 3.318 & 0.001 \\
\hline D(LRDP) & -0.004 & 0.017 & -0.227 & 0.820 \\
\hline $\mathrm{D}(\mathrm{LK})$ & -0.492 & 0.101 & -4.897 & 0.000 \\
\hline D(LELMRDP) & 0.148 & 0.008 & 17.560 & 0.000 \\
\hline $\mathrm{C}$ & 5.333 & 0.472 & 11.291 & 0.000 \\
\hline
\end{tabular}

The results for the groups of 100, 76 and 44 countries are presented in Table 4 which reveal that R\&D investment is the highly significant factor of value added in economic growth in the longrun. The effect of R\&D investment on economic growth is $0.073 \%$ at $5 \%$ level of significance in 
the long-run while insignificant in the short-run in the group of 100 countries. In the group of 76 countries, the R\&D investment impacts the economic growth by $0.116 \%$ at $5 \%$ significance level. While in the group of 44 developing countries, although the impact of $R \& D$ expenditure on economic growth is positive and significant but its value is lower $(0.077 \%$ at $5 \%$ significance level) than that of developed countries (Table 4).

TABLE 5. Panel ARDL Model Estimation for Comparison Between Different Groups

\begin{tabular}{|c|c|c|c|c|c|c|c|c|}
\hline Variable & Coefficient & Std. Error & t-Statistic & Prob.* & Coefficient & Std. Error & t-Statistic & Prob.* \\
\hline \multirow[t]{2}{*}{ i) } & \multicolumn{4}{|c|}{ Group of 32 OECD Countries } & \multicolumn{4}{|c|}{ Group of 32 Non-OECD Countries } \\
\hline & \multicolumn{8}{|c|}{ Long Run Equation } \\
\hline LRD & 0.279 & 0.044 & 6.286 & 0.000 & \begin{tabular}{|l|l|l} 
& 0.042 \\
\end{tabular} & 0.016 & 2.706 & 0.007 \\
\hline LRDP & 0.223 & 0.046 & 4.844 & 0.000 & -0.024 & 0.018 & -1.346 & 0.179 \\
\hline LK & 0.351 & 0.036 & 9.705 & 0.000 & 0.437 & 0.012 & 36.088 & 0.000 \\
\hline \multirow[t]{2}{*}{ LELMRDP } & 1.153 & 0.164 & 7.024 & 0.000 & \begin{tabular}{l|l} 
& 0.655 \\
\end{tabular} & 0.072 & 9.114 & 0.000 \\
\hline & \multicolumn{8}{|c|}{ Short Run Equation } \\
\hline ECT(-1) & -0.041 & 0.043 & -0.943 & 0.347 & \begin{tabular}{|l|l|} 
& -0.089 \\
\end{tabular} & 0.037 & -2.430 & 0.016 \\
\hline $\mathrm{D}(\mathrm{LRD})$ & -0.022 & 0.032 & -0.680 & 0.497 & -3079.776 & 3316.882 & -0.929 & 0.354 \\
\hline D(LRDP) & -0.016 & 0.040 & -0.406 & 0.685 & -13.460 & 66.031 & -0.204 & 0.839 \\
\hline $\mathrm{D}(\mathrm{LK})$ & 0.194 & 0.021 & 9.037 & 0.000 & 0.089 & 0.022 & 3.972 & 0.000 \\
\hline $\begin{array}{l}\text { D(LELMRDP } \\
\text { ) }\end{array}$ & 0.231 & 0.105 & 2.189 & 0.029 & 0.341 & 0.260 & 1.309 & 0.192 \\
\hline $\mathrm{C}$ & -0.145 & 0.223 & -0.651 & 0.515 & -66.506 & 89.095 & -0.746 & 0.456 \\
\hline \multirow[t]{2}{*}{ ii) } & \multicolumn{4}{|c|}{ Group of 8 Highly Developed Countries } & \multicolumn{4}{|c|}{ Group of 8 Developing Countries } \\
\hline & \multicolumn{8}{|c|}{ Long Run Equation } \\
\hline LRD & 0.614 & 0.091 & 6.763 & 0.000 & \begin{tabular}{|l|l|} 
& 0.170 \\
\end{tabular} & 0.054 & 3.142 & 0.002 \\
\hline LRDP & -0.987 & 0.156 & -6.337 & 0.000 & -0.002 & 0.064 & -0.036 & 0.971 \\
\hline LK & 0.661 & 0.175 & 3.771 & 0.000 & 0.499 & 0.087 & 5.739 & 0.000 \\
\hline \multirow[t]{2}{*}{ LELMRDP } & 0.702 & 0.059 & 11.882 & 0.000 & 0.667 & 0.331 & 2.019 & 0.046 \\
\hline & \multicolumn{8}{|c|}{ Short Run Equation } \\
\hline ECT(-1) & -0.019 & 0.025 & -0.785 & 0.435 & \begin{tabular}{|l|l|} 
& -0.095 \\
\end{tabular} & 0.050 & -1.884 & 0.062 \\
\hline $\mathrm{D}(\mathrm{LRD})$ & 0.066 & 0.036 & 1.833 & 0.070 & -0.035 & 0.041 & -0.857 & 0.393 \\
\hline $\mathrm{D}($ LRDP $)$ & -0.015 & 0.073 & -0.212 & 0.832 & -0.120 & 0.104 & -1.159 & 0.249 \\
\hline $\mathrm{D}(\mathrm{LK})$ & 0.231 & 0.031 & 7.421 & 0.000 & 0.158 & 0.040 & 3.930 & 0.000 \\
\hline D(LELMRDP & 0.225 & 0.156 & 1.439 & 0.154 & 0.416 & 0.279 & 1.494 & 0.138 \\
\hline $\mathrm{C}$ & -0.019 & 0.025 & -0.785 & 0.435 & -0.093 & 0.063 & -1.463 & 0.146 \\
\hline \multirow[t]{2}{*}{ ii) } & \multicolumn{4}{|c|}{ Group of 3 East Asian Countries } & \multicolumn{4}{|c|}{ Group of 3 South Asian Countries } \\
\hline & \multicolumn{8}{|c|}{$\begin{array}{ll}\text { Long Run Equation } \\
\end{array}$} \\
\hline LRD & 0.205 & 0.043 & 4.744 & 0.000 & \begin{tabular}{|l|l|} 
& 0.0381 \\
\end{tabular} & 0.093 & 4.115 & 0.001 \\
\hline LRDP & 0.118 & 0.058 & 2.036 & 0.049 & -0.051 & 0.026 & -1.917 & 0.072 \\
\hline LK & 0.420 & 0.027 & 15.570 & 0.000 & 0.553 & 0.022 & 24.980 & 0.000 \\
\hline \multirow[t]{2}{*}{ LELMRDP } & -0.538 & 0.163 & -3.300 & 0.002 & \begin{tabular}{|l|l|} 
& -0.729 \\
\end{tabular} & 0.356 & -2.049 & 0.056 \\
\hline & \multicolumn{8}{|c|}{ Short Run Equation } \\
\hline ECT(-1) & -0.331 & 0.128 & -2.575 & 0.014 & \begin{tabular}{l|l} 
& -0.006 \\
\end{tabular} & 0.156 & -0.038 & 0.970 \\
\hline $\mathrm{D}(\mathrm{LRD})$ & -0.024 & 0.061 & -0.402 & 0.690 & 0.009 & 0.074 & 0.118 & 0.908 \\
\hline D(LRDP) & 0.029 & 0.059 & 0.487 & 0.629 & 0.059 & 0.171 & 0.345 & 0.734 \\
\hline $\mathrm{D}(\mathrm{LK})$ & 0.091 & 0.092 & 0.986 & 0.330 & 0.046 & 0.121 & 0.375 & 0.712 \\
\hline D(LELMRDP & 0.166 & 0.293 & 0.566 & 0.575 & 0.458 & 0.569 & 0.804 & 0.432 \\
\hline $\mathrm{C}$ & 7.213 & 2.849 & 2.532 & 0.016 & -0.001 & 3.116 & 0.000 & 1.000 \\
\hline
\end{tabular}

The results of 32 OECD and 32 Non-OECD countries are shown in Table 5. The results indicate that positive and significant relationship exists between R\&D expenditure and GDP in both groups of countries but the effect of R\&D investment is higher in OECD countries $(0.27 \%)$ as compared to the Non-OECD countries $(0.042 \%)$. Similar results have been seen in the second 
category of 8 highly developed European countries and 8 developing countries. The effect of $\mathrm{R} \& \mathrm{D}$ is $0.61 \%$ and $0.17 \%$ in highly developed and developing countries, respectively (Table 5). The results of the third category of 3 East Asian countries and 3 South Asian countries indicate a positive and significant impact of R\&D investment on economic growth at $5 \%$ significance level. The impact is higher in East Asian countries than in South Asian countries.

TABLE 6. Short Run Coefficient of 76 Individual Countries by Panel ARDL

\begin{tabular}{|c|c|c|c|c|c|c|c|c|c|c|c|}
\hline \multirow{2}{*}{$\begin{array}{c}\text { S.No } \\
\cdot \\
\end{array}$} & \multirow{2}{*}{ Country } & \multicolumn{2}{|c|}{ D(LRD) } & \multicolumn{2}{|c|}{ ECT(-1) } & \multirow{2}{*}{ S.No. } & \multirow{2}{*}{ Country } & \multicolumn{2}{|c|}{ D(LRD) } & \multicolumn{2}{|c|}{ ECT(-1) } \\
\hline & & Coeff & Prob.* & Coeff & Prob.* & & & Coeff & Prob.* & Coeff & Prob.* \\
\hline 1 & Algeria & -0.004 & 0.000 & -0.121 & 0.000 & 39 & Lithuania & 0.242 & 0.000 & 0.018 & 0.000 \\
\hline 2 & Australia & 0.049 & 0.000 & 0.050 & 0.000 & 40 & $\begin{array}{l}\text { Luxembour } \\
\mathrm{g}\end{array}$ & 0.227 & 0.001 & 0.000 & 0.063 \\
\hline 3 & Austria & 0.007 & 0.000 & 0.003 & 0.000 & 41 & Macao & -0.040 & 0.010 & -0.006 & 0.001 \\
\hline 4 & Bahrain & -0.002 & 0.000 & 0.033 & 0.000 & 42 & Malaysia & -0.056 & 0.000 & 0.016 & 0.003 \\
\hline 5 & Belgium & -0.001 & 0.003 & 0.012 & 0.000 & 43 & Mexico & -0.016 & 0.001 & -0.037 & 0.000 \\
\hline 6 & Brazil & -0.007 & 0.000 & -0.014 & 0.000 & 44 & Morocco & -0.004 & 0.267 & -0.085 & 0.000 \\
\hline 7 & Bulgaria & 0.011 & 0.000 & 0.025 & 0.000 & 45 & Netherlands & -0.089 & 0.001 & 0.012 & 0.000 \\
\hline 8 & Canada & 0.053 & 0.000 & 0.007 & 0.000 & 46 & $\begin{array}{l}\text { New } \\
\text { Zealand }\end{array}$ & -0.032 & 0.005 & 0.012 & 0.000 \\
\hline 9 & Chile & 0.001 & 0.000 & 0.038 & 0.000 & 47 & Nigeria & 14.144 & 0.813 & 0.065 & 0.082 \\
\hline 10 & China & -0.002 & 0.000 & -0.028 & 0.000 & 48 & Norway & -0.091 & 0.000 & 0.009 & 0.000 \\
\hline 11 & Croatia & 0.070 & 0.000 & 0.014 & 0.000 & 49 & Oman & 0.086 & 0.001 & 0.015 & 0.000 \\
\hline 12 & Cyprus & 0.098 & 0.002 & 0.004 & 0.000 & 50 & Pakistan & 0.028 & 0.000 & -0.013 & 0.000 \\
\hline 13 & Czech Rep. & -0.002 & 0.347 & 0.027 & 0.000 & 51 & Panama & -0.016 & 0.000 & 0.049 & 0.000 \\
\hline 14 & Denmark & -0.011 & 0.122 & 0.010 & 0.000 & 52 & Philippines & 0.194 & 0.002 & -0.089 & 0.000 \\
\hline 15 & Ecuador & 0.081 & 0.000 & -0.003 & 0.005 & 53 & Poland & 0.209 & 0.000 & 0.126 & 0.000 \\
\hline 16 & Egypt & 0.044 & 0.000 & -0.061 & 0.000 & 54 & Portugal & 0.019 & 0.001 & 0.017 & 0.000 \\
\hline 17 & Finland & 0.052 & 0.001 & 0.007 & 0.000 & 55 & Puerto Rico & -0.225 & 0.104 & -0.268 & 0.000 \\
\hline 18 & France & 0.092 & 0.001 & 0.027 & 0.000 & 56 & Qatar & 2.399 & 0.343 & -0.064 & 0.000 \\
\hline 19 & Germany & 0.242 & 0.001 & 0.034 & 0.000 & 57 & Romania & 0.095 & 0.000 & 0.149 & 0.000 \\
\hline 20 & Greece & 0.033 & 0.014 & 0.017 & 0.000 & 58 & Russia & 0.081 & 0.000 & -0.015 & 0.000 \\
\hline 21 & Guatemala & 0.053 & 0.000 & 0.054 & 0.000 & 59 & Serbia & 0.019 & 0.000 & -0.016 & 0.000 \\
\hline 22 & Hong Kong & 0.002 & 0.038 & 0.019 & 0.000 & 60 & Singapore & 0.036 & 0.009 & 0.050 & 0.000 \\
\hline 23 & Hungary & 0.171 & 0.000 & 0.021 & 0.000 & 61 & Slovenia & 0.030 & 0.001 & 0.017 & 0.000 \\
\hline 24 & Iceland & -0.025 & 0.156 & 0.010 & 0.000 & 62 & South Africa & -0.044 & 0.002 & 0.064 & 0.000 \\
\hline 25 & India & -0.295 & 0.000 & -0.042 & 0.000 & 63 & Spain & 0.100 & 0.001 & 0.023 & 0.000 \\
\hline 26 & Indonesia & 0.016 & 0.002 & -0.030 & 0.000 & 64 & Sri Lanka & -0.047 & 0.000 & -0.213 & 0.000 \\
\hline 27 & Iran & 0.001 & 0.179 & -0.087 & 0.000 & 65 & Sweden & 0.084 & 0.000 & 0.018 & 0.000 \\
\hline 28 & Iraq & -0.019 & 0.857 & 0.021 & 0.003 & 66 & Switzerland & -0.162 & 0.096 & 0.019 & 0.000 \\
\hline 29 & Ireland & -0.032 & 0.534 & 0.047 & 0.000 & 67 & Tanzania & -0.041 & 0.000 & -0.040 & 0.000 \\
\hline 30 & Israel & 0.153 & 0.000 & 0.031 & 0.000 & 68 & Thailand & 0.035 & 0.001 & -0.040 & 0.000 \\
\hline 31 & Italy & 0.135 & 0.000 & 0.007 & 0.000 & 69 & Tunisia & 0.036 & 0.001 & 0.063 & 0.000 \\
\hline 32 & Japan & 0.124 & 0.000 & -0.058 & 0.000 & 70 & Turkey & 0.030 & 0.001 & 0.085 & 0.000 \\
\hline 33 & Jordan & 0.340 & 0.000 & 0.025 & 0.000 & 71 & Ukraine & 0.061 & 0.014 & -0.041 & 0.000 \\
\hline 34 & Kazakhstan & 0.024 & 0.000 & 0.114 & 0.000 & 72 & UAE & 0.148 & 0.004 & 0.062 & 0.000 \\
\hline 35 & Kenya & 0.120 & 0.005 & -0.026 & 0.000 & 73 & UK & 0.139 & 0.001 & 0.015 & 0.000 \\
\hline 36 & Korea, Rep. & -0.047 & 0.017 & -0.147 & 0.000 & 74 & Uruguay & 0.019 & 0.000 & 0.021 & 0.000 \\
\hline 37 & Kuwait & -0.028 & 0.000 & 0.095 & 0.000 & 75 & Uzbekistan & 0.086 & 0.583 & -0.178 & 0.000 \\
\hline 38 & Latvia & 0.076 & 0.000 & 0.030 & 0.000 & 76 & Vietnam & 0.280 & 0.001 & -0.043 & 0.000 \\
\hline
\end{tabular}


The results of a short run coefficient for 76 individual countries are presented in Table 6 which show a mix scenario. In some countries, the positive and significant effect of R\&D investment is seen while in some countries the situation is reverse for short-run. 25 countries out of 78 , show a negative relationship between $R \& D$ investment and economic growth while 53 countries show the positive association between the variables.

The results show that the value of Error Correction Term (ECT) is significant at 5\% level, has negative sign, and show value between zero and one in all nine different models. This indicates that our models are fine and have no serious econometric issues. ECT indicates the long run speed of adjustment. ECT tells when the dependent variable goes away from its equilibrium point, how much time it requires to come back to its equilibrium. The coefficients of the error correction term are $-0.001,-0.83$, and -1.31 for group of 100,76 , and 44 countries, respectively and are significant at 5\% level. The speed of adjustment from previous year's disequilibrium in economic growth (GDP) to current year's equilibrium can be seen as $0.1 \%, 83 \%$, and $131 \%$ for group of 100, 76 and 44 countries, respectively.

\section{Granger Causality}

Granger argued that the presence of a cointegrating vector indicates that Granger causality must exist in at least one direction. A variable Granger causes other variable, if it helps to forecast its future values. The results of the Pairwise Granger Causality test are reported in Table 7. As our focus is to find the causal relationship between R\&D investment and economic growth, we are not presenting results of the other variables. The results indicate that $\mathrm{P}$ value is less than $5 \%$ significance level so we may reject the null hypothesis and accept an alternative. It means that LRD Granger causes LY, as well as LY Granger causes LRD. It indicates that bi-directional causality between economic growth and R\&D investment is present.

Table 7. Pairwise Granger Causality Test

\begin{tabular}{l|l|c|c}
\hline Null Hypothesis: & Obs & F-Statistic & Prob. \\
\hline LRD does not Granger Cause LY & 1900 & 11.236 & 0.000 \\
\hline LY does not Granger Cause LRD & & 8.764 & 0.000 \\
\hline
\end{tabular}

\section{Discussion of Results}

On the basis of our empirical results, we may state that R\&D expenditures are directly and significantly associated with economic growth in the long-run as well as in the short-run. Analysis of the data of top 100 economies of the world reveals that $1 \%$ increase in a country's R\&D expenditures brings about $0.07 \%$ rise in the country's economic growth. This group is comprised of 66 developing countries and 34 developed countries. The impact of R\&D investment on economic growth in the group of 100 countries $(0.07 \%)$ is less as compared to the second group of 76 countries $(0.11 \%)$ which is comprised of 44 developing countries and 32 developed countries. In the third group of 44 developing countries, the impact on economic growth is $0.07 \%$. This indicates that increase in the number of developing countries in the group decreases the impact of R\&D expenditure on economic growth.

To verify these results, we divided the countries into two groups of an equal number (32) developed and developing countries. The results show that the impact of R\&D expenditures on economic growth is $0.279 \%$ in the developed countries, while it is only $0.042 \%$ in the developing countries; impact is almost seven times higher in the developed countries. The second category contains group of eight selected developed countries (Japan, Germany, Korea Rep., France, United Kingdom, Italy, Australia, and Austria) with very high R\&D budget, while the comparative group consist of eight selected developing countries (Bahrain, Brazil, China, India, 
Malaysia, Singapore, South Africa, Thailand) with high R\&D budget in 2015. Similar to the results mentioned above, the impact of $\mathrm{R} \& \mathrm{D}$ investment on economic growth was higher in the developed countries $(0.614 \%)$ than in the developing countries $(0.170 \%)$. When the 3 East Asian countries (China, Japan, Korea) were compared with the 3 South Asian countries (India, Malaysia, Pakistan). The results indicate that the impact of R\&D investment on economic growth is more than five times higher in the selected three East Asian countries compared to the selected three South Asian countries.

The results of present study endorse all economic and others theories which speak that chances of R\&D expenditure impacting economic growth in developed countries are higher than in the developing countries; conceivably, the developed countries have better infrastructure, human resources, universities, $R \& D$ organizations to utilize the $R \& D$ budget for economic growth. The developing countries have to improve their $R \& D$ infrastructure and environment to take advantage of R\&D investment. It has also been shown through empirical testing that there is a bidirectional causal relationship between economic growth and R\&D expenditures. This mean that economic growth cannot be accelerated without R\&D expenditure, and R\&D expenditure cannot be enhanced or raised without economic growth.

\section{Conclusion and Policy Recommendations Conclusion}

The purpose of the study was to examine the relation among the R\&D expenditure and economic growth. For this purpose, the top 100 economies of the world (as per average GDP ranking for 21 years over the period of 1995-2015) were selected for the study. Panel ARDL test was performed on nine different groups of countries. In the long-run, positive and significant association between R\&D expenditure and economic growth was found in all different groups of countries. Results indicate that impact of R\&D investment on economic growth in the group of 100 countries is $0.073 \%$ (at $1 \%$ significant level) as compared to the group of 76 countries that is $0.11 \%$. For further clarification, ARDL test was performed exclusively in 44 developing countries (which have data of all five variables) and $0.077 \%$ impact of $\mathrm{R} \& \mathrm{D}$ investment on economic growth at 5\% significant level in the long-run was found. It infers that $1 \%$ increase in R\&D investment lead to $0.073 \%, 0.11 \%$, and $0.77 \%$ increase in the economic growth (GDP) in the group of 100,76 , and 44 countries, respectively. The impact of R\&D expenditure on economic growth varied in different groups of the economies. The reason is that 100 countries was comprised of 66 developing countries and 34 developed countries while the group of 76 countries consisted of 32 developed and 44 developing countries. As many of the developing countries have negative growth trends in GERD in different years (Table 5) and variations in data which resulted in the lower value of impact.

To make the results more meaningful, comparative analysis in three categories of countries (each consisting two groups of similar number of countries) was made. The result showed positive impact of R\&D expenditure on economic growth in 32 developed $(0.279 \%)$ and 32 developing countries $(0.042 \%)$ at $5 \%$ significant level in the long-run. The huge difference was observed between these two groups of countries with regards to impact of R\&D investment on economic growth. The impact of R\&D investment was almost 7 times higher in 32 developed countries compared to developing countries. In the second category, comparison was made between 8 highly developed countries (Japan, Germany, Korea Rep., France, United Kingdom, Italy, Australia, and Austria) and 8 developing countries (Bahrain, Brazil, China, India, Malaysia, Singapore, South Africa, Thailand) having high R\&D budget in 2015. The results were similar to the first category of countries. The long-run coefficient value indicated the positive and significant impact of R\&D investment on economic growth and impact was almost 4 times higher for the group of 8 developed countries than the 8 developing countries. In the last category, the study compared the impact of R\&D investment in 3 East Asian countries (Japan, 
Korea, and China) with the 3 South Asian countries (India, Malaysia, and Pakistan). The results showed that the impact of R\&D investment on economic growth was positive and significant in both the groups at 5\% significance level in long-run, however, the impact was more than 5 times higher in the East Asian Countries.

The results indicated that short-run coefficients of R\&D investment in all nine different models were insignificant at 5\% level. These results are in lines with all the concepts and economic theories of $R \& D$ investment which state that the impact of $R \& D$ expenditure does not appear within days, months or even a year. The impact starts appearing after some years' it is a long-run phenomenon, not a short-run.

Growth rate is the best yardstick to measure the efficiency of any sector or indicator. The current study reported the growth rate of GERD showing negative growth rate in many developing as well as some developed countries. If we have a such type of data (having negative growth trends) and try to correlate it with the GDP growth, we cannot expect a positive result. That is why, a few studies have found the negative relation between R\&D investment and economic growth, which is not a meaningful result. $R \& D$ investment is a hidden investment whose results appear in the form of abstract benefits (human capital, idea, quality, or state rather than a concrete object), and after a reasonable lag period. The political leaders in developing countries have the tendency to look for tangible and prompt results. Their focus is on winning the elections by showing some tangible output to their voters within the short period of time.

Further, to understand the insight of R\&D investment, to unveil the important economic benefits, the presence of localization and spill over effects of R\&D investment, the current study suggests the diamond model. The Diamond model describes all the possible channels through which maximum benefits can be achieved by investment in R\&D. The universities and R\&D organizations are production house of knowledge in form of patents, publications, skills, creations, inventions, varieties, and discoveries. In the second stage, the role of industry starts which takes the inventions and discoveries developed by the researchers and produces those at a large scale and market them; consequently making profits maximum. An increase in the production capacity of the industrial \& agricultural sector and enhancement of efficiency in service sector would bring about the increase of economic growth of the country. As the R\&D expenditure is the best-hidden investment that accelerates the economic growth silently, the R\&D expenditure is the best accelerator for economic growth.

\section{Policy Recommendations}

On the basis of empirical evidence and theoretical discussion, the current study proposes a road map and some policy guidelines, particularly for developing countries.

Figure 5. Road map to accelerate the economic growth through R\&D investment 


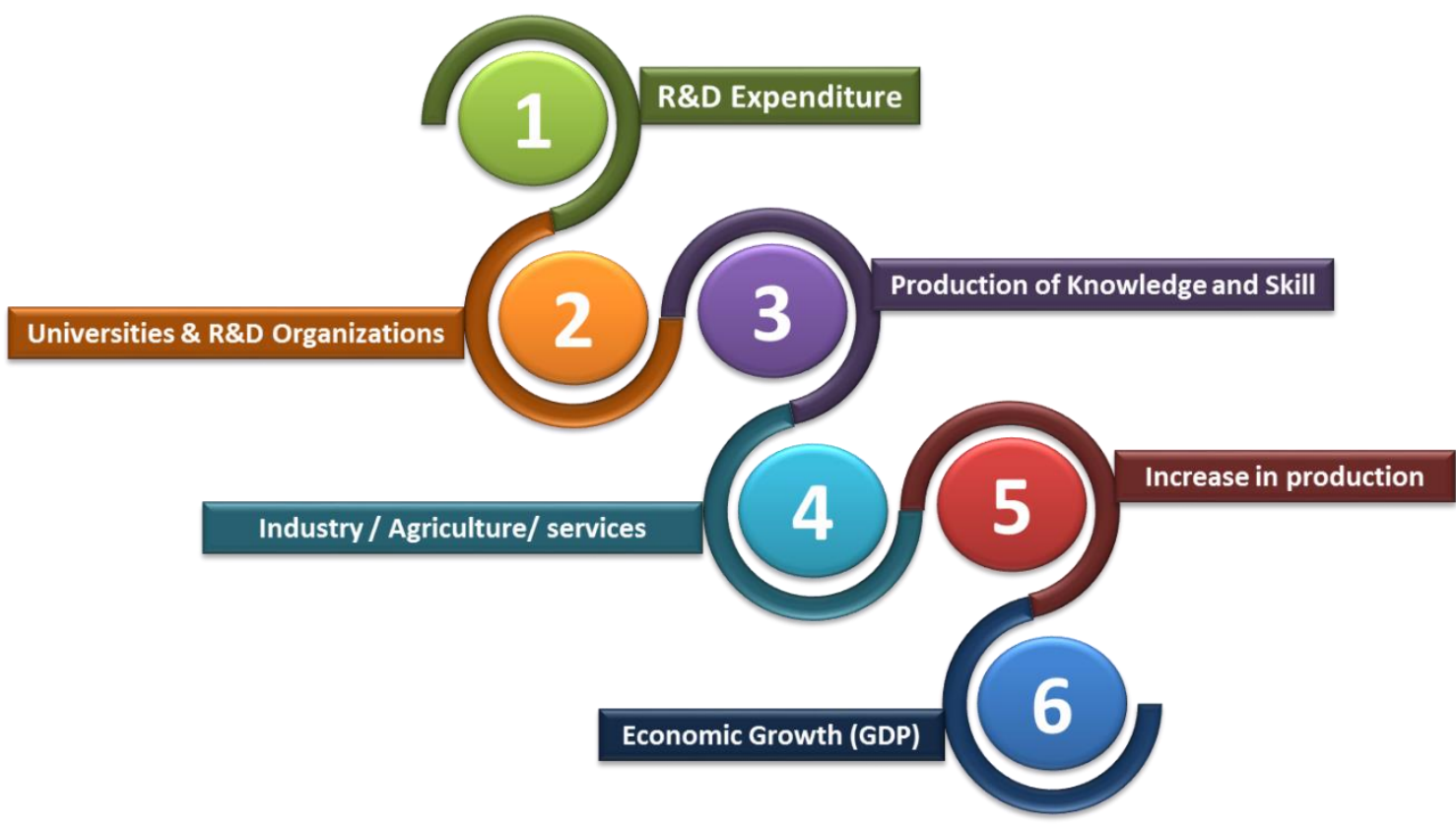

\section{Road Map}

The proposed road map consists of six steps to accelerate the economic growth through R\&D investment (Figure 6): 1n the first step, the government would enhance the R\&D expenditure. In the second step, this $R \& D$ budget is properly utilized by universities and $R \& D$ organizations through different research projects. In the third step, the universities and R\&D organizations would emphasize on applied and genuine research which could result in production of knowledge which ultimately would be beneficial for industrial, agricultural and service sectors. In the step four, industrial, agricultural and service sectors would apply the research and knowledge to increase the production. In the step five, when the production capacity of industry and agriculture sector will increase, the supply of products (commodities tend to be raw materials like corn, wheat, copper, crude oil, etc.) in the market would increase resulting in the price-fall following the supply and demand rule. This will enhance the social well-being of the people. In the step six, enhancement of production would contribute to increasing the GDP, consequently, the economic growth of the country would increase.

\section{Recommendations}

For developing countries, following policy guidelines are suggested:

i. There is a dire need for developing countries to enhance their $\mathrm{R} \& \mathrm{D}$ as well as education budget on urgent basis.

ii. Proper utilization of R\&D budget as well as infrastructure of universities and R\&D organizations is required. The developing countries also need to setup world class research labs to achieve the goals.

iii. Creating a leadership and management development system at university level; people from institutions who have executive responsibilities and decision-making powers of considerable scope must have leadership as well as managerial and administrative qualities and skills.

iv. Refining and promoting teaching excellence to facilitate skill development; a program for the scholarship of teaching and learning for teachers and professors should be launched by the governments.

v. Bridging the gaps between policy and practice as well as between R\&D and production.

vi. Taking steps to support the synthesis of existing knowledge and to build and expand the national knowledge base. 
vii. Promote university-industries linkages; government officials, academics and industrialists sit together and develop pragmatic approaches to enhance the linkages between industry and university.

viii. Improve educational tools and materials (revise curriculum and syllabi at all levels in accordance with industry needs).

ix. Try to follow the pattern of developed countries like Finland, Denmark etc. where the private spending on $R \& D$ is higher than the public spending. In developing countries private sector should come forward and invest in R\&D and government should provide incentives to such private organizations like relaxation in excise rates, tariffs, duties, quotas etc.

\section{Limitations of Study}

The study is limited in coverage to 100 countries out of the 264 countries and territories of the world as per World Bank (WB, WDI, 2017). Data of all five indicators for all 100 countries included in the study was not available, therefore missing values have been estimated by linear interpolation and forecasting where required, but we were forced to use zero for estimation values where data of the country is not available. Comparison between the East Asian and South Asian countries was limited to only three countries in each group.

\section{References}

Aghion, P., \& Howitt, P. (1992). A model of Grwoth through Creative Destruction. Econometrica, 60 (2), 323-351.

Aghion, P., \& Howitt, P. (1998). Endogenous Growth Theory, (Cambridge, Massachusetts: The MIT Press).

Alam, I., Quazi, R. (2003). Determinants of Capital Flight from Bangladesh: Evidence from Cointegration Analysis. International Review of Applied Economics, 17(1), 85-103

Arrow, K. (1962). The economic implications of learning by doing. Review of Economic Studies,29, 155-73.

Ayres, R., \&Warr, B. (2009). The economic growth engine- how energy and work drive material prosperity. Cheltenham: Edward Elgar Publishing.

Bacovic, M. and Lipovina-Bozovic, M. (2010). Knowledge accumulation and Economic Growth, Podgorica: University of Montenegro and ASECU, 37-50, http://www.ekonomija.ac.me/sites/ekonomija.bildstudio.me/files/multimedia/fajlovi/vijesti/ 2013/02/bacovic_maja_lipovina_milena_knowledge_accumulation_and_economic_grow th.pdf. Accessed 3 January 2017.

Barro R. (1997). Determinants of Economic Growth: A Cross-Country Empirical Study. MIT Press.

Bell, M., \& Pavitt, P. (1993). Technological accumulation and industrial growth: Contrasts between developed and developing countries. Industrial and Corporate Change, 2(2), 157211

Bilbao-Osorio, B. and Rodriguez-Pose, A. (2004), From R\&D to Innovation and Economic Growth in the EU. Growth and Change, 35 (4), 434-455

Bor, J.Y., Chuang Y.C., Lai, W.W., Yang, M.C. (2012). OECD A dynamic general equilibrium model for public R\&D investment in Taiwan. Economic Modelling, 27, 171-183.

Coe, D., Helpman, E., \&Hoffmaister, A. (1997).North-South R\&D spill overs. Economic Journal, 107(440), 134-49.

Conlisk, J. (1967). A Modified Neoclassical Growth Model with Endogenous Technical Change. The Southern Economic Journal, 34, 199-208.

Conlisk, J. (1969). A Neoclassical Growth Model with Endogenously Positioned Technical Change Frontiers. Economic Journal, 79, 348-362.

Crespi, G., \& Zuniga, P. (2011). Innovation and productivity: Evidence from Six Latin American Countries. World development, 40(2), 273-290. 
Engle, R. F. and C. W. J. Granger (1987). Co-integration and Error Correction: Representation, Estimation and Testing. Econometrica, 55, 251-276.

Frantzen, D. 2000. R\&D, Human Capital and International Technology Spillovers: A Crosscountry Analysis. Scandinavian Journal of Economics, 102(1), 57-75

Freire-Seren, M.J. (1999). Aggregate R\&D expenditure and endogenous economic growth (UFAE and IAE Working Papers No. WP 43699). Barcelona, Spain: Unitat de Fonaments de 1'Analisi Economica (UAB) and Institut d'Analisi Economica (CSIC).

Freire-sern, M. J. (2001). R\&D-expenditure in an endogenous growth model. Journal of Economics, 741, 39-62.

García-Manjón, J. V. \& Romero-Merino, M. E. (2012), 'Research, development, and firm growth. Empirical evidence from European top R\&D spending firms', Research Policy, 41: 6, 1084-92

Genc, Murat Can \&Atasoy, Yesim.(2010), the relationship between R\&D expenditure and economic growth.Panel data analysis. The Journal of Knowledge Economy \& knowledge Management, V, Fall, 27-34

Gocer, I. (2013). Ar-Ge Harcamalarının Yuksek Teknolojili UrunI'hracat1, Dis, Ticaret Dengesive Ekonomik Buyume Uzerindeki Etkileri [Effects of R\&D expenditures on high technology exports, balance of foreign trade and economic growth]. Maliye Dergisi, (165), 215-40.

Griffith, R., Redding, S., and Reenen, J.V. 2004. Mapping the two faces of R\&D: productivity growth in a panel of OECD industries. The Review of Economics and Statistics, November 2004, 86(4), 883-895

Grossman, G.M. and Helpman, E. (1991). Innovation and Growth in the Global Economy, The MIT Press, London, England

Gulmez, A., \& Yardımcıoglu, F. (2012). OECD Ulkelerinde Ar-Ge Harcamaları ve Ekonomik Buyume I'lis, kisi: Panel Es, butunles, me ve Panel Nedensellik Analizi (1990-2010) [The relationship between R\&D expenditures and economic growth in OECD Countries: Panel cointegration and panel causality analyses (1990-2010)]. Maliye Dergisi, (163), 33553.

Gumus, E., \&Celikay, F. (2015). R\&D Expenditure and Economic Growth: New Empirical Evidence. Margin -The Journal of Applied Economic Research, 9(3), 205-217

Gyekye, A. B., Oseifuah, E. K. and Vukor-Quarshie, G. N. K. (2012). The impact of research and development on socioeconomic development: Perspectives from selected developing economies, Journal of Emerging Trends in Economics and Management Sciences, 3: 6, pp. 915-22

Hall, B. H. (1996). The private and social returns to research and development. In Bruce L.R. Smith \& Claude E. Barfield (Eds.), Technology, R\&D, and the Economy (pp.140-183). Washington, D.C.

Hall, B. H., J. Mairesse, \& Mohnen, P. (2010). Chapter 24-Measuring the returns to R\&D. In H. H. Bronwyn, \& R. Nathan, Handbook of the economics of innovation (pp. 1033-1082). Burlington: Academic Press

Inekwe, J. N. (2015). The Contribution of R\&D Expenditure to Economic Growth in Developing Economies. Social Indicators Research, 124, 727-745.

Jones, C, I., (1995b). Time Series Test of Endogenous Growth Models, Quarterly Journal of Economics, 495-525.

Katz, M. (1986). An analysis of cooperative research and development. Rand Journal of Economics, 17, 527-543.

Kaur, M. \& Singh, L. (2016). R\&D expenditure and economic growth: An empirical analysis. International Journal of Technology Management \& Sustainable Development, 15(3), 195213

Keller, W. (1998). Are international R\&D spillovers trade related? Analysing spillovers among 
Lichtenberg, F.R. (1992). R\&D investment and international productivity differences NBER Working Paper Series No. 4161. Cambridge, MA: National Bureau of Economic Research.

Lucas, R. (1988). On the mechanics of economic development. Journal of Monetary Economics, 22, 3-42.

OECD. (2002). Frascati Manual 2002: Proposed standard practice for a survey on research and experimental development. In The measurement of scientific and technological activities. OECD publishing.

Park, W. G. (1998). A theoretical model of government research and growth. Journal of Economic Behavior \& Organization, 341, 69-85.

Pedroni, P. 2004. Panel cointegration: asymptotic and finite sample properties of pooled time series tests with an application to the PPP hypothesis. Econometric Theory, 20: 597-627.

Pesaran, M. H., and Shin, Y. (1999). An Autoregressive Distributed Lag Modelling Approach to Cointegration Analysis' in S Strom, (ed.), Econometrics and Economic Theory in the 20th Century: The Ragnar Frisch Centennial Symposium, Cambridge: Cambridge U P.

Pesaran, M.H. and B. Pesaran (1997), Microfit 4.0: Interactive Econometric Analysis, Oxford University Press (forthcoming). randomly matched trade partners. European Economic Review, 42(8), 1469-81.

Phelps, E. (1966). Models of Technical Progress and the Golden Rule of Research. Review of Economic Studies, 33, 133-145.

Poorfaraj, A., Samimi, A. J; Keshavarz, H. 2011. Knowledge and Economic Growth: Evidence from Some Developing Countries. Journal of Education and Vocational Research, 1(1), 21-25.

Romer, P. (1986).Increasing returns and long-run growth. Journal of Political Economy, 94, 1002-1037.

Romer, P. (1987). Growth based on increasing returns due to specialization. American Economic Review,

Romer, P. (1994).The Origins of Endogenous Growth. Journal of Economic Perspectives, 1, 322.

Romer, P. M. (1990). Endogenous technological change,Journal of Political Economy, 98, S71S102.

Sadraoui, T. and Zina, N. B. (2009). A Dynamic Panel Data Analysis for R\&D Cooperation and Economic Growth, International Journal of Foresight and Innovation Policy, 5 (4), 218233

Salter, A. J., \& Martin, B. R. (2001). The economic benefits of publicly funded basic research: a critical review. Research Policy, 303, 509-532.

Samimi, A. J. and Alerasoul, S. M. (2009). R\&D and Economic Growth: New Evidence from Some Developing Countries. Australian Journal of Basic and Applied Sciences, 3 (4), 3464-3469.

Sarac, T.B. (2009). Aras,tırma-Gelis tirme Harcamalarının Ekonomik Büyüme Üzerindeki Etkisi: Panel Veri Analizi [The effect of research-development expenditures on economic growth: A panel data]. Econ Anadolu 2009: Anadolu International Conference in Economics, Eskis, ehir, Turkey.

Schumpeter, J. (1942). Capitalism, socialism, and democracy. New York, NY: Harper.

Segerstrom, P. (2000). The long-run growth effects of R\&D subsidies. Journal of Economic Growth, 305, 277-305.

Shell, K. (1967).'A Model of Innovative Activity and Capital Accumulation. In: Shell, K. (ed.), Essays on the Theory of Optimal Economic Growth, MIT Press, Cambridge, 67-85.

Sokolov-Mladenović, S., Cvetanović, S., \&Mladenović, I. (2016). R\&D expenditure and economic growth: EU28 evidence for the period 2002-2012.Economic ResearchEkonomskaIstraživanja, 29(1), 1005-1020.

Solow, R. (1957). Technical change and aggregate production function. Review of Economics and Statistics, 39, 312-320. 
Solow, R. M. (1956). A contribution to the theory of economic growth. Quarterly Journal of Economics, 70, 65-94.

Swan, Trevor W. (November 1956). Economic growth and capital accumulation. Economic Record, 32 (2), 334-361.

Sylwester, K. (2001). R\&D and economic growth. Knowledge, Technology \& Policy, 13(4), 7184.

Tiryakioglu Murad. (2006). Research and development-relationship of economic growth: Application of selected OECD countries. Afyon Kocatepe University Institute of Social Science, Afyon.

Todaro, M. P. (1997), Economic Development. (6th ed.). New York: Longman, (Chapter 4).

Todaro, M., \& Smith, S. (2006). Economic development. New York, NY: Pearson Education Limited.

Ulku, H. (2004). R\&D, invention and economic growth: An empirical analysis. IMF working papers, https://ideas.repec.org/p/ekd/003307/330700146.Html, Accessed 10 January 2017.

Ulku, H. (2007). R\&D, innovation, and growth: evidence from four manufacturing sectors in OECD countries. Oxford Economic Papers, 59, 513-535

Uzawa, H. (1965). Optimum Technical Change in an Aggregate Model of Economic Growth. International Economic Review, 6, 18-31.

Van Pottelsberghe del la Potterie, B., \&Guellec, D. (2004). From R\&D to productivity growth: Do the institutional settings and the source of funds of R\&D matter? Oxford Bulletin of Economics and Statistics, 66(3), 353-78.

Zhang, W. B. (1993). Government's research policy and economic growth, capital, knowledge and economic structure. Research Policy, 22, 327-336. 